\title{
Chemical and Physicochemical Pretreatment of Lignocellulosic Biomass: A Review
}

\author{
Gary Brodeur, ${ }^{1}$ Elizabeth Yau, ${ }^{1}$ Kimberly Badal, ${ }^{1}$ John Collier, ${ }^{1}$ \\ K. B. Ramachandran, ${ }^{2}$ and Subramanian Ramakrishnan ${ }^{1}$ \\ ${ }^{1}$ Department of Chemical and Biomedical Engineering, FAMU-FSU College of Engineering, Tallahassee, FL 32312, USA \\ ${ }^{2}$ Department of Biotechnology, Indian Institute of Technology, Chennai 600036, India
}

Correspondence should be addressed to Subramanian Ramakrishnan, sramakrishnan@fsu.edu

Received 26 December 2010; Accepted 18 March 2011

Academic Editor: Praveen Vadlani

Copyright ( 2011 Gary Brodeur et al. This is an open access article distributed under the Creative Commons Attribution License, which permits unrestricted use, distribution, and reproduction in any medium, provided the original work is properly cited.

\begin{abstract}
Overcoming the recalcitrance (resistance of plant cell walls to deconstruction) of lignocellulosic biomass is a key step in the production of fuels and chemicals. The recalcitrance is due to the highly crystalline structure of cellulose which is embedded in a matrix of polymers-lignin and hemicellulose. The main goal of pretreatment is to overcome this recalcitrance, to separate the cellulose from the matrix polymers, and to make it more accessible for enzymatic hydrolysis. Reports have shown that pretreatment can improve sugar yields to higher than $90 \%$ theoretical yield for biomass such as wood, grasses, and corn. This paper reviews different leading pretreatment technologies along with their latest developments and highlights their advantages and disadvantages with respect to subsequent hydrolysis and fermentation. The effects of different technologies on the components of biomass (cellulose, hemicellulose, and lignin) are also reviewed with a focus on how the treatment greatly enhances enzymatic cellulose digestibility.
\end{abstract}

\section{Introduction}

The goals stated in the recent roadmap published by the United States Department of Energy (US DOE) [1] is to accelerate biomass to energy conversion research, helping make biofuels practical and cost competitive by 2012 and offering the potential to displace up to $30 \%$ of the nation's current gasoline use by 2030. A major source of biomass which will form the focus of energy research is the lignocellulosic biomass which is particularly well suited for energy applications because of its large-scale availability, low cost, and environmentally benign production. In particular, many energy production and utilization cycles based on cellulosic biomass have near-zero greenhouse gas emissions on a lifecycle basis [2-4].

One of the key steps in the biochemical platform of the biomass to fuels or chemicals process being developed by the US DOE is depolymerization of cellulose to glucose by fungal cellulases before fermentation to ethanol or other products by microbial biocatalysts (Biomass Multiyear Program Plan, March 2008, Office of Biomass Program, EERE, DOE).
Novozymes, an enzyme production company, estimated (2007 values) that the cost of enzymes to depolymerize cellulose and hemicellulose to sugars for fermentation would be about 40-100 times higher than the cost of enzymes for starch hydrolysis to glucose on a per gallon ethanol basis [5]. Major cellulase producers estimate (2010) the cost of fungal cellulases to be about $\$ 0.50$ per gallon [6] of cellulosic ethanol produced. Since this price of enzymes is about $25 \%$ of the total cost of ethanol production, new strategies for reducing enzyme loading need to be identified to reduce the cost of enzymes in bioprocessing of biomass to fuels and chemicals.

The primary obstacle impeding the more widespread production of energy from biomass feedstocks is the general absence of low-cost technology for overcoming the recalcitrance of these materials [7-10]. Lignocelluloses are composed of cellulose, hemicellulose, lignin, extractives, and several inorganic materials. Cellulose is a linear syndiotactic (alternating spatial arrangement of the side chains) homopolymer composed of D-anhydroglucopyranose units which are linked together by $\beta$ - $(1 \rightarrow 4)$-glycosidic bonds. 
Taking the dimer cellobiose as the basic unit, cellulose can be considered as an isotactic (identical spatial arrangement of the side chains) polymer of cellobiose. The cellulose chains are packed into microfibrils which are stabilized by hydrogen bonds (Figure 1) [1]. These fibrils are attached to each other by hemicelluloses and amorphous polymers of different sugars as well as other polymers such as pectin and covered by lignin. Hemicellulose has a lower molecular weight than cellulose and is composed of mainly pentoses (like xylose and arabinose) and hexoses (like mannose, glucose, and galactose). It also has considerable side chain branching consisting of hydrolysable polymers. Lignin is an amorphous polymer whose attributes include providing rigidity to the plant cell wall and resistance against microbial attack. The cellulose microfibrils which are present in the hemicellulose-lignin matrix are often associated in the form of bundles or macrofibrils. The structure of these naturally occurring cellulose fibrils is mostly crystalline in nature and highly resistant to attack by enzymes (limited accessibility of cellulose chains). Cellulose is more susceptible to enzymatic degradation in its noncrystalline form. The presence of lignin also impedes enzymatic hydrolysis, as enzymes bind onto the surface of lignin and hence do not act on the cellulose chains [11]. If enzymatic hydrolysis of biomass is to proceed in typical processes, the crystalline structure of cellulose needs to be disrupted, accessible area increased, and the lignin and hemicellulose separated from the cellulose before treatment with enzymes (Figure 1). The process of pretreatment is considered to be one of the expensive steps in the conversion of lignocellulosic feedstock's to ethanol and accounts for nearly $\$ 0.30 /$ gallon of ethanol produced [1].

\section{Production of Biofuels by Fermentation}

Pretreatment of the biomass is followed by enzymatic hydrolysis to produce simple sugars, fermentation of sugars to produce biofuels, and then product separation $[13,14]$. The pretreatment step is key for subsequent enzymatic hydrolysis and fermentation steps in order to maximize the volumetric productivity of the desired product. Cellulose and hemicellulose can be broken down into simple sugars either enzymatically or by acid hydrolysis. The hydrolysis product, six carbon sugars (hexoses), can easily be fermented to ethanol, while only a few microorganism strains can ferment the five carbon sugars (pentoses) $[7,8,15,16]$. There has been considerable research done in genetically modifying organisms to produce strains that are capable of fermenting both glucose and xylose to useful chemicals (lactic acid) $[13,17]$. The process in which the cellulose is broken down and fermented at the same time in the presence of the microorganism is called simultaneous saccharification and fermentation (SSF) [15, $18,19]$. SSF has been the preferred route to the production of biofuels and chemicals, since the operations of both hydrolysis and fermentation are done in the same reactor vessel thus reducing costs. In SSF, the fungal cellulases are most active at $50^{\circ} \mathrm{C}$ to $55^{\circ} \mathrm{C}$, while the microbes ferment effectively at temperatures below $35^{\circ} \mathrm{C}$. Because of the mismatch in the optima (cellulase activity and the microbial biocatalyst),

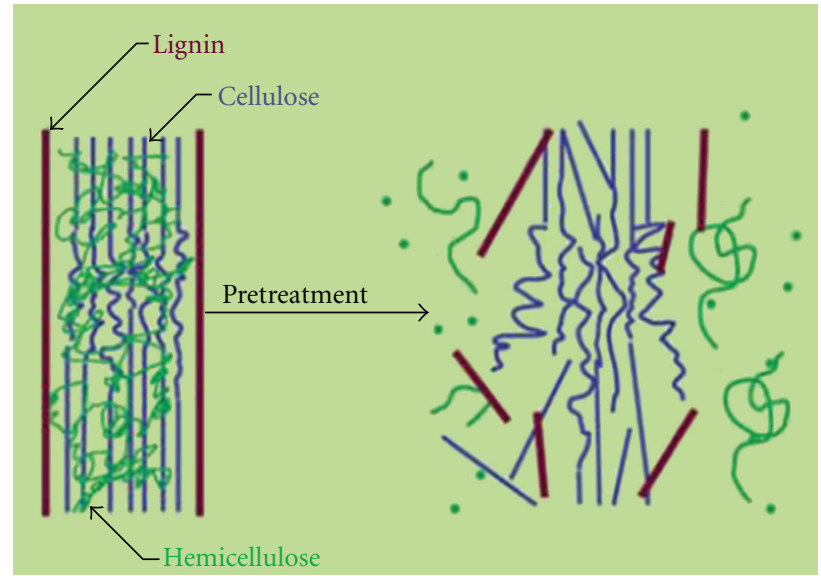

FIGURE 1: Schematic representation (adapted from [1, 12]) of the matrix of polymers in which cellulose exists. Pretreatment of biomass by different methods removes hemicellulose and lignin from this matrix before hydrolysis.

simultaneous SSF of cellulose to fuels and chemicals is carried out at a compromise temperature that is close to that of the microbial biocatalyst than that for cellulase activity. This compromise temperature of SSF leads to higher than needed enzyme loading to depolymerize cellulose to glucose with an associated higher cost of cellulases. Recent work in the group of Shanmugam and coworkers $[13,17,20]$ has shown that by genetically modifying microorganisms to operate (ferment) at a higher temperature of $50^{\circ} \mathrm{C}$ to $55^{\circ} \mathrm{C}$ results in a lower cellulase loading, thus reducing the cost of the process and the final product. Current efforts in the literature are focussed on how to combine pretreatment and SSF to maximize productivity and to make the overall process economically efficient. This paper will just focus on the first step of pretreatment and how this affects the subsequent processing steps.

\section{Goals of Pretreatment}

Numerous pretreatment strategies have been developed to enhance the reactivity of cellulose and to increase the yield of fermentable sugars. Typical goals of pretreatment include (1) production of highly digestible solids that enhances sugar yields during enzyme hydrolysis, (2) avoiding the degradation of sugars (mainly pentoses) including those derived from hemicellulose, (3) minimizing the formation of inhibitors for subsequent fermentation steps, (4) recovery of lignin for conversion into valuable coproducts, and (5) to be cost effective by operating in reactors of moderate size and by minimizing heat and power requirements. The goal of this paper is to review promising pretreatment technologies and to discuss recent developments which have greatly aided the production of biofuels. For each technology, a brief process description is first given with recent developments, and then the feedstocks on which these technologies are used are highlighted, followed by discussion of the technology's 
advantages and disadvantages. Recent results from the corresponding author's laboratories in solvent pretreatment are given with a goal of trying to integrate pretreatment with SSF.

\section{Pretreatment Categories}

Pretreatment technologies are usually classified into physical, chemical, physicochemical, and biological. Physical pretreatment involves breakdown of biomass size and crystallinity by milling or grinding. Improved hydrolysis results due to the reduction in crystallinity and improved mass transfer characteristics from reduction in particle size. The energy requirements for physical pretreatments are dependent on the final particle size and reduction in crystallinity of the lignocellulosic material. In most cases where the only option available for pretreatment is physical, the required energy is higher than the theoretical energy content available in the biomass. This method is expensive and likely will not be used in a full-scale process. Biological pretreatment, as normally defined, involves the use of microorganisms (mainly fungi) to degrade lignin and hemicellulose but leave the cellulose intact [21-23]. Lignin degradation occurs through the action of lignin degrading enzymes secreted by the fungi. Even though biological pretreatments involve mild conditions and are of low cost, the disadvantages are the low rates of hydrolysis and long pretreatment times required compared to other technologies [19]. Current efforts in biological pretreatments are in combining this technology with other pretreatments and in developing novel microorganisms for rapid hydrolysis $[21,22,24]$. Since both physical and biological processes are not cost competitive compared to the chemical and physicochemical pretreatments, they will not be reviewed in this current paper. Table 1 highlights the advantages and disadvantages of the pretreatment technologies that would be discussed in this work. A brief description of these technologies is given below.

\subsection{Chemical Pretreatments}

4.1.1. Alkaline. Alkaline pretreatment involves the use of bases, such as sodium, potassium, calcium, and ammonium hydroxide, for the pretreatment of lignocellulosic biomass. The use of an alkali causes the degradation of ester and glycosidic side chains resulting in structural alteration of lignin, cellulose swelling, partial decrystallization of cellulose [2527], and partial solvation of hemicellulose [27, 28]. Sodium hydroxide has been extensively studied for many years, and it has been shown to disrupt the lignin structure of the biomass, increasing the accessibility of enzymes to cellulose and hemicellulose [29-32]. Another alkali that has been used for the pretreatment of biomass is lime. Lignocellulosic feedstocks that have been shown to benefit from this method of pretreatment are corn stover, switchgrass, bagasse, wheat, and rice straw $[19,33-36]$.

Sun and coworkers [37] studied the effectiveness of different alkaline solutions by analyzing the delignification and dissolution of hemicellulose in wheat straw. They found that the optimal condition was using $1.5 \%$ sodium hydroxide for 144 hours at $20^{\circ} \mathrm{C}$, which resulted in $60 \%$ release of lignin and $80 \%$ release of hemicellulose. Xylose was the major component of the hemicellulose fractions and the hydrolysates from pretreatment, while glucose and galactose were present in smaller amounts. Recently, Zhao and coworkers [31] showed the effectiveness of sodium hydroxide pretreatment for hardwoods, wheat straw, switchgrass, and softwoods with less than $26 \%$ lignin content. Sodium hydroxide pretreatment has also been shown to increase biogas production from corn stover by $37 \%$ compared to that of untreated cellulose [32]. The conditions for alkaline pretreatment are usually less severe than other pretreatments. It can be performed at ambient conditions, but longer pretreatment times are required than at higher temperatures. The alkaline process involves soaking the biomass in alkaline solutions and mixing it at a target temperature for a certain amount of time. A neutralizing step to remove lignin and inhibitors (salts, phenolic acids, furfural, and aldehydes) is required before enzymatic hydrolysis. A recent approach to lime pretreatment eliminates the solid-liquid separation step after neutralization by neutralizing the lime with carbon dioxide before hydrolysis resulting in $89 \mathrm{wt} \%$ glucose recovery from leafstar rice straw [34]. Park and coworkers [34] also used this method to test SSF which resulted in an ethanol yield that was $74 \%$ of the theoretical value using a mixture of Saccharomyces cerevisae and Pichiastipitis after 79 hours of fermentation at $30^{\circ} \mathrm{C}$.

The advantage of lime pretreatment is that the cost of lime required to pretreat a given quantity of biomass is lowest among alkaline treatments. For example, in 2005, the estimated cost of materials was $\$ 70 /$ ton hydrated lime compared to $\$ 270 /$ ton fertilizer grade ammonia and $\$ 320 /$ ton for $50 \mathrm{wt} \% \mathrm{NaOH}$ and $45 \mathrm{wt} \% \mathrm{KOH} \mathrm{[19].} \mathrm{Though} \mathrm{lime}$ pretreatment is energy intensive, $\mathrm{CaCO}_{3}$ can be recovered by precipitation with $\mathrm{CO}_{2}$ after solid-liquid separation [38]. If the method developed by Park and coworkers is used, $\mathrm{CO}_{2}$ for neutralizing lime can be supplied from a fermentor or a heater to reduce costs. However, Park's process makes it difficult to separate $\mathrm{CaCO}_{3}$ from other solid particles after hydrolysis and fermentation. A number of studies have combined alkaline pretreatment with other pretreatment methods, such as the wet oxidation, steam explosion, ammonia fiber explosion, and ammonia recycled percolation, which are discussed in later sections. Recently, Zhao and coworkers [31] showed that the sugar yield from switchgrass could be improved by combining alkaline pretreatment with radiofrequency-based dielectric heating, which allows pretreatment of high solid content and uniform temperature profile in the pretreated biomass. It is hypothesized that the use of radiofrequency dielectric heating accelerates the disruption of the lignocelluloses structure by causing an explosion effect among the particles, thus resulting in higher xylose and glucose yields compared to the pretreatment with alkali and conventional heating.

4.1.2. Wet Oxidation. Wet oxidation utilizes oxygen as an oxidizer for compounds dissolved in water. There are two reactions that occur during this process. One is a low 
TABLE 1: Advantages and disadvantages of different pretreatment methods of lignocellulosic biomass.

\begin{tabular}{|c|c|c|}
\hline Pretreatment method & Advantages & Disadvantages \\
\hline \multirow{2}{*}{ Alkali } & (i) Efficient removal of lignin & (i) High cost of alkaline catalyst \\
\hline & (ii) Low inhibitor formation & (ii) Alteration of lignin structure \\
\hline \multirow{3}{*}{ Acid } & (i) High glucose yield & (i) High costs of acids and need for recovery \\
\hline & (ii) Solubilizes hemicellulose & (ii) High costs of corrosive resistant equipment \\
\hline & & (iii) Formation of inhibitors \\
\hline \multirow{3}{*}{ Green solvents } & (i) Lignin and hemicellulose hydrolysis & (i) High solvent costs \\
\hline & $\begin{array}{l}\text { (ii) Ability to dissolve high loadings of different } \\
\text { biomass types }\end{array}$ & (ii) Need for solvent recovery and recycle \\
\hline & (iii) Mild processing conditions (low temperatures) & \\
\hline \multirow{3}{*}{ Steam } & (i) Cost effective & (i) Partial hemicellulose degradation \\
\hline & $\begin{array}{l}\text { (ii) Lignin transformation and hemicellulose } \\
\text { solubilization }\end{array}$ & $\begin{array}{l}\text { (ii) Acid catalyst needed to make process efficient with } \\
\text { high lignin content material }\end{array}$ \\
\hline & $\begin{array}{l}\text { (iii) High yield of glucose and hemicellulose in } \\
\text { two-step process }\end{array}$ & (iii) Toxic compound generation \\
\hline \multirow{3}{*}{ LHW } & $\begin{array}{l}\text { (i) Separation of nearly pure hemicellulose from rest } \\
\text { of feedstock }\end{array}$ & (i) High energy/water input \\
\hline & (ii) No need for catalyst & $\begin{array}{l}\text { (ii) Solid mass left over will need to be dealt with } \\
\text { (cellulose/lignin) }\end{array}$ \\
\hline & (iii) Hydrolysis of hemicellulose & \\
\hline \multirow{4}{*}{ AFEX } & $\begin{array}{l}\text { (i) High effectiveness for herbaceous material and } \\
\text { low lignin content biomass }\end{array}$ & (i) Recycling of ammonia is needed \\
\hline & (ii) Cellulose becomes more accessible & $\begin{array}{l}\text { (ii) Less effective process with increasing lignin } \\
\text { content }\end{array}$ \\
\hline & (iii) Causes inactivity between lignin and enzymes & (iii) Alters lignin structure \\
\hline & (iv) Low formation of inhibitors & (iv) High cost of ammonia \\
\hline \multirow{3}{*}{ ARP } & (i) Removes majority of lignin & (i) High energy costs and liquid loading \\
\hline & (ii) High cellulose content after pretreatment & \\
\hline & (iii) Herbaceous materials are most affected & \\
\hline \multirow{3}{*}{ Supercritical fluid } & (i) Low degradation of sugars & (i) High pressure requirements \\
\hline & (ii) Cost effective & (ii) Lignin and hemicelluloses unaffected \\
\hline & (iii) Increases cellulose accessible area & \\
\hline
\end{tabular}

temperature hydrolysis reaction and the other is a high temperature oxidation reaction [39]. Typically, the procedure for wet oxidation consists of drying and milling lignocellulosic biomass to obtain particles that are $2 \mathrm{~mm}$ in length, to which water is added at a ratio of $1 \mathrm{~L}$ to $6 \mathrm{~g}$ biomass. A compound usually $\mathrm{Na}_{2} \mathrm{CO}_{3}$, is introduced to the mixture to reduce the formation of byproducts. Air is pumped into the vessel until a pressure of $12 \mathrm{bar}$ is reached. This method of pretreatment is performed at $195^{\circ} \mathrm{C}$ for a range of 10 to 20 minutes [4042].

Wet oxidation can be used to fractionate lignocellulosic material by solubilizing hemicellulose and removing lignin $[39,43]$. It has been shown to be effective in pretreating a variety of biomass such as wheat straw, corn stover, sugarcane bagasse, cassava, peanuts, rye, canola, faba beans, and reed to obtain glucose and xylose after enzymatic hydrolysis [40, 41, 43-46]. Biomass such as straw, reed, and other cereal crop residues have a dense wax coating containing silica and protein which is removed by wet oxidation [47]. For pretreated wheat straw (pretreatment time of 10 minutes), Pederson and Meyer [42] obtained yields of 400 and $200 \mathrm{~g} / \mathrm{kg}$ dry matter for glucose and xylose, respectively, after 24 hours at $50^{\circ} \mathrm{C}$ using an enzyme mixture of $36 \mathrm{FPU} / \mathrm{g}$ Celluclast$1.5 \mathrm{~L}$ and $37 \mathrm{CBU} / \mathrm{g}$ of Novozyme-188. Difficult biomass such as grape stalk (which contains tannins, a chemical that complicate delignification) has also been shown to benefit wet oxidation with up to $50 \%$ cellulose conversion compared to $25 \%$ conversion with sulphuric acid pretreatment [48].

During wet oxidation, lignin is decomposed to carbon dioxide, water, and carboxylic acids $[40,43]$. The amount of lignin removed after pretreatment ranges from $50 \%$ to $70 \%$ depending on type of biomass pretreated and the conditions used. For bagasse with a pretreatment time of 15 minutes $50 \%$ of lignin was removed which resulted in $57.4 \%$ conversion of cellulose compared to only $35 \%$ lignin removal and $48.9 \%$ cellulose conversion for steam explosion, explained later, under the same conditions [41]. However, Martín and coworkers also found that the amount of byproducts formed was almost always higher for pretreatment by oxidation than by steam explosion. Byproducts obtained included 
succinic acid, glycolic acid, formic acid, acetic acid, phenolic compounds, and furfural which would have negative effects on further downstream processing due to inhibition.

Wet oxidation can be combined with other pretreatment methods to further increase the yield of sugars after enzymatic hydrolysis $[47,49-52]$. Combining wet oxidation with alkaline pretreatment has been shown to reduce the formation of byproducts, thereby decreasing inhibition [53]. In combination with steam explosion, in a process called wet explosion, the biomass not only undergoes the chemical reaction described above but also undergoes physical rupture [50]. The advantages to combining wet oxidation with steam explosion includes the ability to process larger particle sizes and to operate at higher substrate loadings, up to $50 \%$ substrate [51]. Georgieva and coworkers [51] were able to obtain a cellulose conversion of $70 \%$, a hemicellulose conversion of $68 \%$ and an ethanol yield of $68 \%$ for SSF using wet explosion. Biomass conversion has also been shown to benefit from the addition of an acid soaking step prior to wet explosion, since acid pretreatment helps to hydrolyze the hemicelluloses, while wet explosion will expose more enzyme binding sites [50].

4.1.3. Acid. Acid pretreatment involves the use of concentrated and diluted acids to break the rigid structure of the lignocellulosic material. The most commonly used acid is dilute sulphuric acid $\left(\mathrm{H}_{2} \mathrm{SO}_{4}\right)$, which has been commercially used to pretreat a wide variety of biomass types-switchgrass $[54,55]$, corn stover [56, 57], spruce (softwood) [58], and poplar [59, 60]. Dilute sulphuric acid has traditionally been used to manufacture furfural [61] by hydrolyzing the hemicellulose to simple sugars, such as xylose, which continues to convert into furfural. Other acids have also been studied, such as hydrochloric acid $(\mathrm{HCl})$ [62], phosphoric acid $\left(\mathrm{H}_{3} \mathrm{PO}_{4}\right)[63,64]$, and nitric acid $\left(\mathrm{HNO}_{3}\right)[65]$. Due to its ability to remove hemicellulose, acid pretreatments have been used as parts of overall processes in fractionating the components of lignocellulosic biomass [63]. Acid pretreatment (removal of hemicellulose) followed by alkali pretreatment (removal of lignin) results in relatively pure cellulose.

This chemical pretreatment usually consists of the addition of concentrated or diluted acids (usually between $0.2 \%$ to $2.5 \% \mathrm{w} / \mathrm{w}$ ) to the biomass, followed by constant mixing at temperatures between $130^{\circ} \mathrm{C}$ and $210^{\circ} \mathrm{C}$. Depending on the conditions of the pretreatment, the hydrolysis of the sugars could take from a few minutes to hours [66-72].

Recent articles [35, 73, 74] have reviewed the development of acid pretreatment of biomass over the years and highlighted the advantages and disadvantages and the optimum conditions of operation. A key advantage of acid pretreatment is that a subsequent enzymatic hydrolysis step is sometimes not required, as the acid itself hydrolyses the biomass to yield fermentable sugars. Hemicellulose and lignin are solubilized with minimal degradation [75], and the hemicellulose is converted to sugars with acid pretreatment. However, extensive washing and/or a detoxification step [66, $71]$ is required to remove the acid before a fermentation step $[68,69]$. Due to the corrosive nature and toxicity of most acids, an adequate material for the reactor is required in order to withstand the required experimental conditions and corrosiveness of the acids. Another drawback is the production of fermentation inhibitors like furfural and HMF (hydroxymethyl furfural) that reduces the effectiveness of the pretreatment method and further processes $[66,70]$.

As mentioned before different types of biomass have proven to be effectively treated by the acid pretreatment. Softwoods were studied by Nguyen and coworkers [68], showing that the sugar yield could be maximized using a two-stage diluted sulphuric acid pretreatment process. Sun and Cheng [70] studied bermudagrass and rye straw. After a 48-hour enzymatic hydrolysis of pretreated bermudagrass and rye straw with $1.5 \%$ sulphuric acid, the total reducing sugars were found to be $197.1 \mathrm{mg} / \mathrm{g}$ and $229.3 \mathrm{mg} / \mathrm{g}$ of dry biomass. Other studies done by Saha and coworkers $[66,71]$ showed that the maximum sugar yield of wheat straw was $565 \pm 10 \mathrm{mg} / \mathrm{g}$ ( $76 \%$ yield based on total carbohydrate content) and that of rice hull was $287 \pm 3 \mathrm{mg} / \mathrm{g}(60 \%$ yield based on total carbohydrate content). Under these conditions, no furfural and hydroxymethyl furfural were produced. Marzialetti and coworkers [64] studied the acid hydrolysis of loblolly pine using a number of different acids (triflulororacetic acid-TFA, $\mathrm{HCl}, \mathrm{H}_{2} \mathrm{SO}_{4}, \mathrm{HNO}_{3}$, and $\mathrm{H}_{3} \mathrm{PO}_{4}$ ). The effect of the type of acid, $\mathrm{pH}$, reaction temperature, and reaction time on hydrolysis products such as monosaccharides (mannose, glucose, galactose, xylose, and arabinose) and the subsequent degradation products, 5-hydroxymethyl-2-furaldehyde (HMF) and 2-furaldehyde (furfural), is reported using a batch reactor. Trifluoroacetic acid (TFA) is found to yield the highest amount of overall soluble monosaccharides (similar to 70\% yield from the hemicellulose fraction) at $150^{\circ} \mathrm{C}$ at $\mathrm{pH} 1.65$. TFA was found to be the most "gentle" acid, leading to limited monosaccharide degradation among the acids used.

The optimum conditions for the acid pretreatment depend highly on the targeted sugars and the purpose of the pretreatment. Lloyd and Wyman [76] found that the optimal conditions for obtaining the maximum sugar yield depends on whether the goal is to maximize the yield after the pretreatment or after the enzymatic hydrolysis of the pretreated solids or if the goal is to obtain maximum yield after both steps. In addition, finding the optimal conditions is extremely important to reduce the formation of inhibitory products that will reduce the efficiency of the fermentation step.

4.1.4. Green Solvents. Processing of lignocellulosic biomass with ionic liquids (IL) and other solvents has gained importance in the last decade due to the tunability of the solvent chemistry and hence the ability to dissolve a wide variety of biomass types. Ionic liquids are salts, typically composed of a small anion and a large organic cation, which exist as liquids at room temperature and have very low vapor pressure. The chemistry of the anion and cation can be tuned to generate a wide variety of liquids which can dissolve a number of biomass types-corn stover [78], cotton [79], bagasse [80], switchgrass [81], wheat straw [82], and woods 
TABLE 2: Solubility of cellulose dissolved in different ILs (adapted from [77]). For the cellulose column, the numbers in brackets correspond

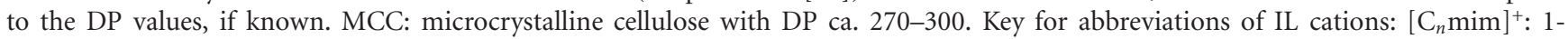
alkyl-3-methylimidazolium ( $n=$ number of carbons in the alkyl chain); $\left[\mathrm{C}_{n} \mathrm{mmim}\right]^{+}: 1$-alkyl-2,3-dimethylimidazolium $(n=$ number of carbons in the alkyl chain); $[\text { Amim }]^{+}: 1$-allyl-3-methylimidazolium; $[\text { Ammim }]^{+}: 1$-allyl-2,3-dimethylimidazolium; $\left[\mathrm{C}_{4} \mathrm{mP}_{y}\right]^{+}: 1$-butyl-3methylpyridinium; $\left[\mathrm{Bu}_{4} \mathrm{P}\right]^{+}$: tetrabutylphosphonium.

\begin{tabular}{|c|c|c|c|}
\hline IL & Cellulose & Method & Solubility \% \\
\hline$\left[\mathrm{C}_{2} \mathrm{mim}\right] \mathrm{Cl}$ & Avicel & Heat, $100^{\circ} \mathrm{C}$ & 10 \\
\hline$\left[\mathrm{C}_{3} \mathrm{mim}\right] \mathrm{Cl}$ & Avicel & Heat, $100^{\circ} \mathrm{C}$ & 0.5 \\
\hline$\left[\mathrm{C}_{4} \mathrm{mim}\right] \mathrm{Cl}$ & Avicel & Heat, $100^{\circ} \mathrm{C}$ & 20 \\
\hline$\left[\mathrm{C}_{4} \mathrm{mim}\right] \mathrm{Cl}$ & Pulp (1000) & Heat & 10 \\
\hline$\left[\mathrm{C}_{4} \mathrm{mim}\right] \mathrm{Cl}$ & Pulp (1000) & Microwave & 25 \\
\hline$\left[\mathrm{C}_{5} \mathrm{mim}\right] \mathrm{Cl}$ & Avicel & Heat, $100^{\circ} \mathrm{C}$ & 1.5 \\
\hline$\left[\mathrm{C}_{6} \mathrm{mim}\right] \mathrm{Cl}$ & Pulp (1000) & Microwave & 5 \\
\hline$\left[\mathrm{C}_{6} \mathrm{mim}\right] \mathrm{Cl}$ & Avicel & Heat, $100^{\circ} \mathrm{C}$ & 6.5 \\
\hline$\left[\mathrm{C}_{7} \mathrm{mim}\right] \mathrm{Cl}$ & Avicel & Heat, $100^{\circ} \mathrm{C}$ & 5 \\
\hline$\left[\mathrm{C}_{8} \mathrm{mim}\right] \mathrm{Cl}$ & Avicel & Heat, $100^{\circ} \mathrm{C}$ & 4 \\
\hline$[\mathrm{Amim}] \mathrm{Cl}$ & Pulp (650) & Heat, $80^{\circ} \mathrm{C}$ & 14.5 \\
\hline$[\mathrm{Amim}] \mathrm{Cl}$ & MCC & Ultrasound & 27 \\
\hline$\left[\mathrm{C}_{4} \mathrm{mmim}\right] \mathrm{Cl}$ & Pulp (569) & Heat, $90-130^{\circ} \mathrm{C}$ & 12.8 \\
\hline$\left[\mathrm{C}_{4} \mathrm{mmim}\right] \mathrm{Cl}$ & Pulp (286) & Heat, $90^{\circ} \mathrm{C}$ & 9 \\
\hline$\left[\mathrm{C}_{4} \mathrm{mmim}\right] \mathrm{Cl}$ & Pulp (593) & Heat, $90^{\circ} \mathrm{C}$ & 6 \\
\hline$\left[\mathrm{C}_{4} \mathrm{mmim}\right] \mathrm{Cl}$ & Pulp (1198) & Heat, $90^{\circ} \mathrm{C}$ & 4 \\
\hline$\left[\mathrm{C}_{4} \mathrm{mPy}\right] \mathrm{Cl}$ & Pulp (593) & Heat, $105^{\circ} \mathrm{C}$ & 37 \\
\hline$\left[\mathrm{C}_{4} \mathrm{mim}\right] \mathrm{Br}$ & Pulp (1000) & Microwave & $5-7$ \\
\hline$[\mathrm{Ammim}] \mathrm{Br}$ & Pulp (286) & Heat, $80^{\circ} \mathrm{C}$ & 12 \\
\hline$[\mathrm{Ammim}] \mathrm{Br}$ & Pulp (1198) & Heat, $80^{\circ} \mathrm{C}$ & 4 \\
\hline$\left[\mathrm{C}_{4} \mathrm{mim}\right][\mathrm{SCN}]$ & Pulp (1000) & Microwave & $5-7$ \\
\hline$\left[\mathrm{C}_{2} \operatorname{mim}\right][\mathrm{OAc}]$ & Avicel & Heat, $100^{\circ} \mathrm{C}$ & 8 \\
\hline$\left[\mathrm{C}_{2} \mathrm{mim}\right][\mathrm{OAc}]$ & Avicel (225) & Heat, $110^{\circ} \mathrm{C}$ & 28 \\
\hline$\left[\mathrm{C}_{4} \mathrm{mim}\right][\mathrm{OAc}]$ & MCC & Heat, $70^{\circ} \mathrm{C}$ & 28.5 \\
\hline$\left[\mathrm{C}_{4} \mathrm{mim}\right][\mathrm{OAc}]$ & Avicel & Heat, $100^{\circ} \mathrm{C}$ & 12 \\
\hline$[$ Amim] $][\mathrm{HCOO}]$ & MCC & Heat, $85^{\circ} \mathrm{C}$ & 22 \\
\hline$\left[\mathrm{C}_{4} \mathrm{mim}\right][\mathrm{HCOO}]$ & MCC & Heat, $70^{\circ} \mathrm{C}$ & 12.5 \\
\hline$\left[\mathrm{C}_{4} \mathrm{mim}\right][\mathrm{HCOO}]$ & Avicel (225) & Heat, $110^{\circ} \mathrm{C}$ & 8 \\
\hline$\left[\mathrm{C}_{4} \mathrm{mim}\right]\left[\left(\mathrm{C}_{6} \mathrm{H}_{5}\right) \mathrm{COO}\right]$ & MCC & Heat, $70^{\circ} \mathrm{C}$ & 12 \\
\hline$\left[\mathrm{C}_{4} \mathrm{mim}\right]\left[\left(\mathrm{NH}_{2}\right) \mathrm{CH}_{2} \mathrm{COO}\right]$ & MCC & Heat, $70^{\circ} \mathrm{C}$ & 12 \\
\hline$\left[\mathrm{C}_{4} \mathrm{mim}\right]\left[\mathrm{OHCH}_{2} \mathrm{COO}\right]$ & MCC & Heat, $70^{\circ} \mathrm{C}$ & 12 \\
\hline$\left[\mathrm{Bu}_{4} \mathrm{P}\right][\mathrm{HCOO}]$ & Avicel (225) & Heat, $110^{\circ} \mathrm{C}$ & 6 \\
\hline$\left[\mathrm{C}_{4} \mathrm{mim}\right]\left[\mathrm{HSCH}_{2} \mathrm{COO}\right]$ & MCC & Heat, $70^{\circ} \mathrm{C}$ & 13.5 \\
\hline$\left[\mathrm{C}_{2} \operatorname{mim}\right]\left[\left(\mathrm{CH}_{3} \mathrm{CH}_{2} \mathrm{O}\right)_{2} \mathrm{PO}_{2}\right]$ & Avicel & Heat, $100^{\circ} \mathrm{C}$ & $12-14$ \\
\hline$\left[\mathrm{C}_{1} \operatorname{mim}\right]\left[\left(\mathrm{CH}_{3} \mathrm{O}\right)_{2} \mathrm{PO}_{2}\right]$ & Avicel & Heat, $100^{\circ} \mathrm{C}$ & 10 \\
\hline$\left[\mathrm{C}_{2} \mathrm{mim}\right]\left[\left(\mathrm{CH}_{3} \mathrm{O}\right)(\mathrm{H}) \mathrm{PO}_{2}\right]$ & MCC & Heat, $45^{\circ} \mathrm{C}$ & 10 \\
\hline
\end{tabular}

of different hardness [83] (pine, poplar, eucalyptus, and oak). The low vapor pressure of IL and similar solvents make them more than $99 \%$ recoverable in a number of operations, thus reducing costs of solvent usage. Since no toxic products are formed during the pretreatment operation and since IL are recoverable, they are termed green solvents. Table 2 (adapted from the work of Sun and coworkers [77]) lists the dissolving capacity of different celluloses by a variety of ILs. For an IL to be used in pretreatment of biomass, it should not only have high dissolution capacity, but also low melting point, low viscosity, low/no toxicity, and high stability. Sun and coworkers [77] found out that although the dissolution is greatly affected by the source of cellulose, different degrees of polymerization (DP), and the dissolution conditions (heating method, irradiation, heating temperature, time, etc.), generally, with the same cation, the solubility of cellulose in ILs decreases in the order

$$
\begin{aligned}
{\left[\left(\mathrm{CH}_{3} \mathrm{CH}_{2} \mathrm{O}\right)_{2} \mathrm{PO}_{2}\right]^{-} } & \approx[\mathrm{OAC}]^{-}>\left[\mathrm{SHCH}_{2} \mathrm{COO}\right]^{-} \\
& >[\mathrm{HCOO}]^{-}>\mathrm{Cl}^{-}>\mathrm{Br}^{-} \approx[\mathrm{SCN}]^{-} .
\end{aligned}
$$


Pretreatment with IL involve dissolution of biomass in the solvent at ambient pressures, temperatures of $90^{\circ} \mathrm{C}$ to $130^{\circ} \mathrm{C}$ for varying amounts of time (1 hour-24 hours) [81, 84]. The biomass is then reprecipitated by the addition of water and washed a number of times before enzymatic hydrolysis. The anion of the IL forms hydrogen bonds with cellulose (sugar hydroxyl protons) in a $1: 1$ ratio and breaks up the cellulose crystalline hydrogen bonded structure, thus making it more amorphous and accessible to enzymatic hydrolysis. In addition, the chemistry of the IL can also be tuned to dissolve the hemicellulose and lignin, thus making it suitable to dissolve the different components. It should be mentioned here that the IL dissolves cellulose and generally does not degrade the chains and reduce its degree of polymerization. Also, research studies $[59,81,84]$ have proven that the structure of lignin and hemicellulose are unaltered after treatment with many ILs.

Dadi and coworkers $[85,86]$ studied the enzymatic hydrolysis of Avicel (microcrystalline cellulose formed by acid treatment) regenerated from two different ILs, 1- $n$-butyl3-methylimidazolium chloride and 1-allyl-3-methylimidazoliumchloride. Hydrolysis kinetics of the IL-treated cellulose was significantly enhanced. With appropriate selection of IL treatment conditions and enzymes, the initial hydrolysis rates for IL-treated cellulose were up to 90 times greater than those of untreated cellulose. The enhanced hydrolysis rates were attributed to the amorphous nature of the cellulose on pretreatment. Wyman and coworkers [59] have recently shown the ability of 1-ethyl-3-methylimidazolium acetate [Emim] Ac to dissolve maple wood flour and that the IL has a high solubility for lignin and a low solubility for cellulose. Therefore, they were able to selectively extract the unaltered lignin from the lignocelluloses while simultaneously yielding a highly degradable cellulose fraction. High throughput screening methods to determine the effectiveness of the ILs to dissolve the cellulose have also been recently developed [87]. Work by Nguyen and coworkers [88] have combined ammonia and ionic liquid pretreatment of rice straw to result in $97 \%$ conversion of cellulose to glucose. The ionic liquid in their work was recycled more than 20 times, thus reducing costs.

A limitation in using ionic liquids is the fact they tend to inactivate cellulase. Turner and coworkers [90] studied the hydrolysis of cellulose by $T$. reesei cellulase in 1-butyl3-methyl imidazolium chloride $[\mathrm{Bmim}] \mathrm{Cl}$ and $[\mathrm{Bmim}] \mathrm{BF}_{4}$ that contained $5 \%$ of cellulose in $50 \mathrm{mM}$ citrate buffer, $\mathrm{pH}$ 4.8 , at $50^{\circ} \mathrm{C}$. The hydrolytic rate in the ILs was poor, at least 10 -fold less than that performed in aqueous buffer. Low activity in $[\mathrm{Bmim}] \mathrm{Cl}$ was attributed to the high concentration of the $\mathrm{Cl}^{-}$ion (and was also observed through the addition of $\mathrm{NaCl}$ ) that leads to unfolding and inactivation of the enzymes. This inactivation was irreversible. Hence, one needs to completely regenerate the cellulose after pretreatment and remove all traces of this IL before hydrolysis by cellulases in order to preserve their activity. This introduces a regeneration and separation step into the process which increases the overall cost and precludes the development of a single stage continuous process for conversion of lignocellulosic biomass. Thus, selection of a solvent for pretreatment in which cellulases and microorganisms are active is a key step in the development of the "biorefinery concept" or "consolidated bioprocessing" schemes which try to develop a single-stage continuous process for biomass conversion.

A solvent which has been effective in dissolution of cellulose and has a low vapor pressure similar to that of the ionic liquids is $\mathrm{N}$-methyl morpholine $\mathrm{N}$-oxide (NMMO), also known as the Lyocell solvent used commercially to produce Tencel fibers. NMMO retains all the advantages of the ionic liquids ability to dissolve a variety of lignocellulosic substrates [91-93] without the need to chemically modify them and $>99 \%$ of the solvent can be recovered due to its low vapor pressure [94]. It is also nontoxic and biodegradable as proven by the work of Lenzing and other researchers [95]. Cellulose regenerated from NMMO solutions has also yielded increased rates of hydrolysis by cellulose, thus highlighting its ability to disrupt the crystalline structure of cellulose $[91,92]$.

Recent work (Figure 2-[89]) in the corresponding authors' laboratories has shown that an in situ enzymatic saccharification process is possible with NMMO that eliminates the need to recover regenerated cellulose. Using dissolving pulp as a substrate and a commercially available cellulase (Accellerase 1000), it was shown that initial rates of hydrolysis of cellulose and yield of reducing sugars in the presence of NMMO water was initially higher (at times less than five hours) and overall at least comparable to that of regenerated cellulose when suspended in aqueous solutions (Figure 2(a)). The results shown in Figure 2(a) have also been compared with data from the literature in which cellulose that has been pretreated in different manners is resuspended in aqueous solutions and enzymatic reactions are carried out. The initial rates of hydrolysis and final yields of simple sugars for cellulose dissolved in NMMO are comparable and in most instances higher than values in the literature. Figure 2(b) is an in situ hydrolysis of dissolving pulp (DP of 1160 - the same substrate used in Figure 2(a)) carried out in three different solvents-NMMO and two ionic liquids. The two ionic liquids studied are 1-ethyl-3-methylimidazolium acetate [Emim]Ac and 1-ethyl-3-methylimidazolium diethylphosphate [Emim]DEP. The reason for using these ionic liquids is that both are excellent solvents for dissolution of woody biomass $[96,97]$. Our initial results indicate as shown in Figure 2(b) that the chemical structure of the cellulose solvent $\left(\mathrm{NMMO} / \mathrm{H}_{2} \mathrm{O},[\right.$ Emim $] \mathrm{Ac}$ and [Emim]DEP) has a definite effect on the conversion to sugars with NMMO having the highest conversion. Ultimate conversion of cellulose is $50-60 \%$ lower while using the ionic liquids. This is an indication that these highly polar species might be deactivating the enzymes. This would be especially troublesome for a process in which one would attempt to recycle the solvent and enzyme as is envisioned for the NMMO-based process. Another ionic liquid-1-butyl-3-methylimidazolium chloride $[\mathrm{Bmim}] \mathrm{Cl}$ (used in spinning cellulose fibers and a good solvent for lignocellulosic biomass) was also tested for in-situ hydrolysis. However, there were no sugars released as a function of time indicating that the cellulases were inactivated. Thus, NMMO led to the best yields and high initial rates in comparison with the tested ionic liquids. 


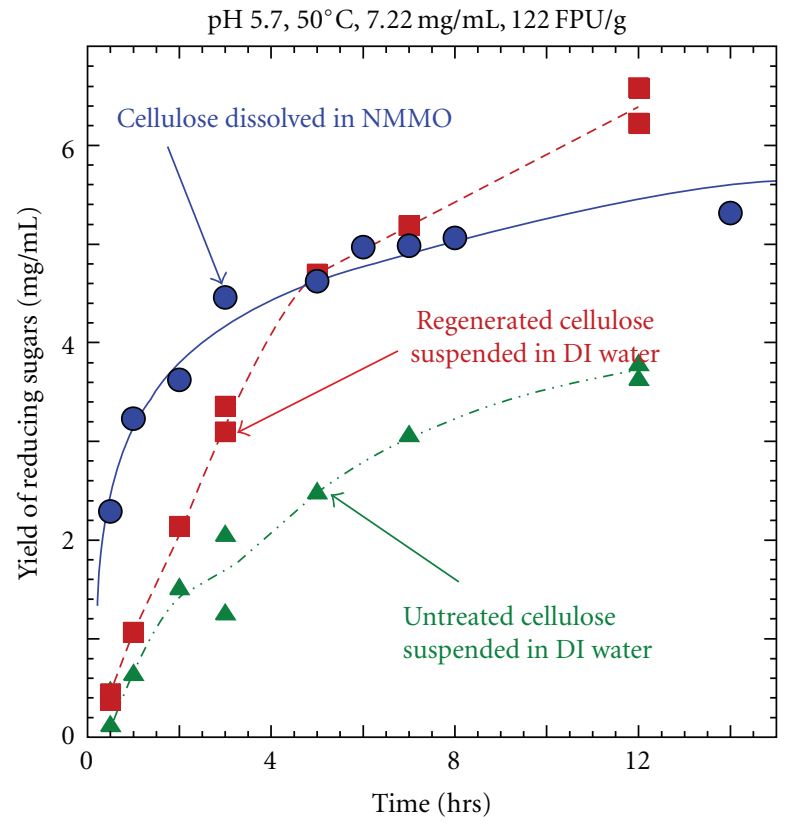

(a)

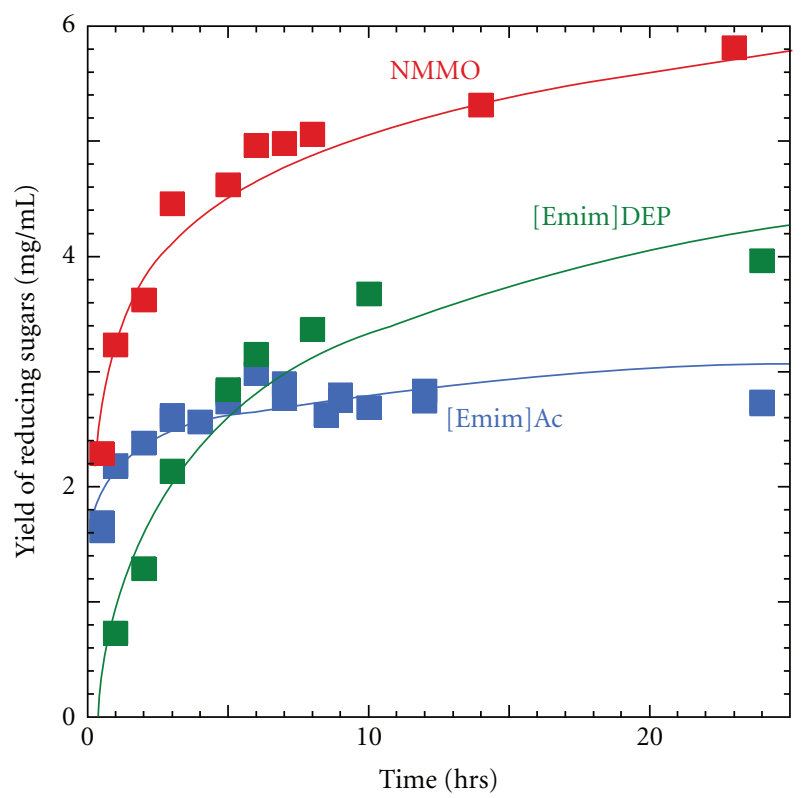

(b)

Figure 2: (a) [89]: Yield of reducing sugars as a function of time for four different samples—cellulose (dissolving pulp of degree of polymerization 1160) dissolved in NMMO (blue circle), regenerated cellulose suspended in DI water (red square), and untreated cellulose suspended in DI water (green triangle). The initial cellulose concentration is $7.22 \mathrm{mg} / \mathrm{mL}, \mathrm{pH}$ is 5.7 and enzyme loading is $122 \mathrm{FPU} / \mathrm{g}$. The lines are drawn to guide the eye. The cellulase used is Accellerase 1000 obtained from Genencor. (b) Yield of sugars as a function of time for in situ hydrolysis of cellulose (the same substrate as in Figure 2(a)) in NMMO and two ionic liquids-[Emim] Ac and [Emim]DEP. The initial cellulose concentration is $7.22 \mathrm{mg} / \mathrm{mL}, \mathrm{pH}$ is 5.7 , and enzyme loading is $122 \mathrm{FPU} / \mathrm{g}$. The lines are drawn to guide the eye.

Further research is needed to evaluate and improve the economics of usage of ILs and NMMO for pretreatment of biomass and to integrate it with SSF. ILs are still expensive and need to be synthesized at lower cost and on a larger scale. The ability of microorganisms to ferment sugars in the presence of these solvents also needs to be tested to carry out a continuous process. Despite these current limitations, pretreatment of lignocellulosic biomass with both NMMO and IL offers a great potential for substantially reducing the costs of pretreatment and in developing a consolidated biorefinery process.

\subsection{Physicochemical Pretreatments}

4.2.1. Steam-Explosion. Steam-Explosion pretreatment is one of the most commonly used pretreatment options, as it uses both chemical and physical techniques in order to break the structure of the lignocellulosic material. This hydrothermal pretreatment method subjects the material to high pressures and temperatures for a short duration of time after which it rapidly depressurizes the system, disrupting the structure of the fibrils. The disruption of the fibrils increases the accessibility of the cellulose to the enzymes during hydrolysis. Particle size is a major contributing factor on the effectiveness of the process, and it has been seen that relatively large particle sizes have been able to yield maximum sugar concentrations. This is a promising finding, as decreasing the particle sizes of the material requires further mechanical processing of the raw material driving up the production costs [98]. Temperatures ranging from $190^{\circ} \mathrm{C}$ to $270^{\circ} \mathrm{C}$ have been used with residence times of 10 minutes and 1 minute, respectively. The starting material and particle sizes that will be processed will be the determining factor on the relationship between temperature and time $[99,100]$.

A two-step steam-explosion pretreatment option has also been looked at in order to solubilize the structure in stages creating an optimum cellulose fraction during hydrolysis. The first step involved temperatures of $180^{\circ} \mathrm{C}$ in order to solubilize and remove the hemicellulose fraction. The second stage used a high-temperature pressurized pretreatment with temperatures up to $210^{\circ} \mathrm{C}$, not exceeding $240^{\circ} \mathrm{C}$, in which the cellulose fraction was subject to breaking down of its carbohydrate linkage $[101,102]$. This two-step process increased the downstream ethanol yield by increasing accessibility to cellulose structure because of the reduction of the hemicellulose fraction. Operation costs also decreased as less enzyme dosage was required due to increased accessibility of the cellulose fraction [102]. However, increased costs of equipment needed for processing and the additional energy usage of a second steam-explosion process is required.

Acid catalysts have been used within the steam explosion process in dilute quantities in order to improve hemicellulose hydrolysis during the pretreatment and cellulose digestibility further on in the process. Dilute acids have the ability to decrease retention time and temperature of current operating systems or allow for the use of softwoods in this 
pretreatment technique, where it was seen to not be originally economical. By decreasing the retention time and temperature with the addition of this acid catalyst, a reduction of inhibitory compounds formed is seen, complete removal of hemicellulose is approached, and the improvement of hydrolysis later on in production is attained [103].

As stated, this process utilizes both chemical and physical interactions in order to effectively break down the lignocellulosic structure. The chemical pretreatment is present in the form of hydrolysis of the glycosidic bonds contained within the hemicellulose and cellulose structure along with the removal and/or redistribution of lignin. Breaking off of these acetyl groups into acetic acid as well as the acidic nature of water at high temperatures will promote further hydrolysis of the hemicellulose [104]. The physical pretreatment comes about during the rapid decompression of the system. This rapid expansion vaporizes the saturated water within the fibrils, breaks down the molecular linkages, and leads to an effective lignocellulosic matrix [105].

The steam-explosion pretreatment process has been a proven technique for the pretreatment of different biomass feedstocks. It is able to generate complete sugar recovery while utilizing a low capital investment and low environmental impacts concerning the chemicals and conditions being implemented and has a higher potential for optimization and efficiency [106]. The large particle sizes that were mentioned can greatly reduce the costs of the overall process. This is due to the fact that obtaining smaller chip sizes may make up to a third of the overall energy cost associated with a particular pretreatment process [107]. Poplar chips (90\% glucose yield after enzymatic hydrolysis compared to $15 \%$ for untreated biomass) [108], olive tree residues (50\% yield of total sugars) [109], herbaceous residues such as corn stover (73\% theoretical sugar yield with dilute sulphuric acid addition) [110], wheat straw $(80 \%$ theoretical conversion yield to ethanol with $0.9 \% \mathrm{H}_{2} \mathrm{SO}_{4}$ addition) [103], and agricultural residues such as B. carinata straw (70-99\% enzymatic hydrolysis yield depending on pretreatment parameters) [98] have all seen dramatic improvements in sugar yields when a steam pretreatment is used over nontreated materials. Softwoods, such as woody hemp (feedstocks considered to be less acetylated; higher lignin content), have even shown increased yields when dilute acids ( $1 \%$ sulphuric acid) are introduced into the system [111]. These dilute acids may also potentially reduce sugar degradation product formation, treatment temperatures, and reaction times or even increase sugar yields in the pretreatment of feedstocks with lower lignin content, that is, $30 \%$ improvement with $1 \%$ sulphuric acid addition with olive tree prunings or increase to $81 \%$ with $3 \%$ sulphuric acid addition to bark containing wood samples [111-113]. However, some disadvantages can be seen when using this process. As mentioned, dilute acids will need to be added during softwood pretreatment or even when increased yields are warranted for lower acetylated feedstocks. These costs will come about not only in the cost of the raw materials (acids) being used, but also in the equipment requirements and the higher formation of degradation products (by the way of monomeric sugar degradation into aldehydes) that would need to be neutralized [114]. These neutralization salts would then need to be separated from the system and disposed [12].

With the inefficient means by which to pretreat many of the different biomass materials into purified cellulose, steps are being taken to move in the direction of complete utilization of the entire lignocellulosic materials that are involved in these conversions. That is, to possibly use less severe or staged pretreatment processes in order to improve hemicellulose and lignin recovery on top of the cellulose results that are already being achieved. Some groups have used a two-stage pretreatment for the utilization of the entire feedstock of lespedeza stalks (alkali-ethanol 2nd treatment) or wheat straw (alkaline peroxide 2nd treatment) in which steam pretreatment is utilized during the first stage followed by extraction and isolation of the degraded hemicellulose fraction from the filtrate $[115,116]$. The final products would then consist of a cellulose rich fraction (directly from steam explosion process), a lignin-rich filtrate (post-2nd stage filtrate treatment), and degraded hemicellulose pellets $[115,116]$. Optimum steam pretreatment conditions of 20 or $22.5 \mathrm{~kg} / \mathrm{m}^{2}$ for 4 minutes were found to yield the highest isolation quantities of high molecular weight hemicelluloses, where this fraction could then be utilized as oligosaccharides.

4.2.2. Liquid Hot Water (LHW). Much like the steamexplosion process, liquid hot water (LHW) pretreatment uses water at elevated temperatures and high pressures to maintain its liquid form in order to promote disintegration and separation of the lignocellulosic matrix. Temperatures can range from $160^{\circ} \mathrm{C}$ to $240^{\circ} \mathrm{C}$ and over lengths of time ranging from a few minutes up to an hour with temperatures dominating the types of sugar formation and time dominating the amount of sugar formation [117]. This process uses many of the same features that steam explosion employs, primarily autohydrolysis, without the rapid decompression, utilizing flow through reactors of varying configurations or batch techniques with the latter being the primary emphasis at the laboratory scale [117-119]. One goal of this process is to completely solubilize hemicellulose and separate it from the rest of the solid material while reducing the formation of inhibitors. The generation of reactive cellulose fibers for the production of pentosans as well as disruption of the entire lignocellulosic matrix is achieved through the cell penetration of the biomass by the water, along with solubilisation of both hemicellulose and lignin by this liquid hot water acting as an acid $[120,121]$.

There are two products that are formed at the outlet of this process: the solubilized hemicellulose-rich slurry and the cellulose-rich solid fraction that are separated from each other [122]. The solubilized product, consisting primarily of oligosaccharides derived from hemicellulose (HDS) (nearly complete removal from solid fraction) and lignin (35-60\% of total starting material) and a minor amount of cellulose (4$15 \%)$, is the primary focus for this particular pretreatment, while the solid fraction will need to be separated and dealt with enzymatically [12]. This HDS-rich fraction is primarily converted to oligomers, while limiting the formation of monomers as long as the $\mathrm{pH}$ is maintained between four 
and seven [12]. Temperature has also been seen to play an important role in the liquid fraction of this pretreatment as the quantity of inhibitor product formation is seen to primarily rise with an increase in temperature. For example, $180^{\circ} \mathrm{C}$ (low end of temperature range) and 30 minutes (moderate-high time-scale range) have seen to be the most cost-effective pretreatment condition for rice straw conversion to glucose [117]. The notable inhibitors or byproducts that are seen to form within the liquid fraction of this process are due to the degradation of pentoses, hexoses, and the lignin present. These products can include furfural, acetic acid, 5-hydroxymethyl-2-furaldehyde (HMF), and formic acid among others [120].

The solid fraction is seen to become more susceptible to enzymatic attack as the cellulose becomes more accessible by the penetration and hydration of cell walls that cause swelling and disruption of the matrix. The primary objective of this pretreatment is, therefore, to lessen the solubilisation of cellulose as much as possible while keeping HDS solubilisation high. After the separation of these two fractions comes a second stage, where the solid product would be subjected to enzymatic hydrolysis forming glucose (cellulose fraction) and xylose (hemicellulose fraction) simple sugars $[117,120]$. In order to be an effective pretreatment, the lignin portion of the lignocellulosic material would want to be included in the liquid fraction as to not inhibit the formation of these simple sugars during enzymatic hydrolysis. It has been seen that lower process temperatures during the LHW treatment will increase the solubilisation of the lignin allowing for higher enzymatic hydrolysis of the solid fraction [120].

This process can be seen as advantageous from a cost standpoint in that no additives such as acid catalysts are required; furthermore, expensive reactor systems are not necessary due to the low corrosive nature of this pretreatment technique and the chemicals that are involved. Neutralization of degradation products will not be needed due to their fractionation and utilization in the liquid fraction. In the same sense, inhibitory products have not been seen to form overwhelmingly in the respective fractions allowing for higher yields under specific conditions within this system. There is, however, the necessity for higher energy costs over steam pretreatment due to the higher pressures and the need for a large amount of water supplied to the system. Like many of the other pretreatments, the severity of the process will depend primarily on the type of lignocellulosic material that is being used and will have to be tailored as such.

4.2.3. Ammonia Fiber Explosion (AFEX). The ammonia fiber/freeze explosion (AFEX) process is another physicochemical process, much like steam explosion pretreatment, in which the biomass material is subjected to liquid anhydrous ammonia under high pressures and moderate temperatures and is then rapidly depressurized. The moderate temperatures $\left(60^{\circ} \mathrm{C}\right.$ to $\left.100^{\circ} \mathrm{C}\right)$ are significantly less than that of the steam explosion process, meaning less energy input and overall costs associated with the process. The degree of disruption to the biomass structure will depend on the temperature, as it will affect the rapidness of the ammonia vaporization within the reactor during depressurization. The residence time can be altered from low (5 to $10 \mathrm{~min}$ ) to moderate $(30 \mathrm{~min})$ lengths depending on the degree of saturation needed for the type of biomass. Ammonia loading is another significant variable that needs to be taken into consideration and is typically chosen to be $1 \mathrm{~kg}$ ammonia per $\mathrm{kg}$ dry biomass for many feedstocks [123-125].

Much like the steam-explosion process, the ammonia and biomass mixture is saturated for a period of time in a pressurized reactor before being released to atmospheric temperature. This rapid expansion of the ammonia gas causes swelling of the biomass feedstock, creating a disruption in the lignin-carbohydrate linkage, hemicellulose hydrolysis and ammonolysis of glucuronic cross-linked bonds, and partial decrystallization of the cellulose structure, all leading to a higher accessible surface area for enzymatic attack [125127]. Recovery of the ammonia gas is then needed to reduce the operating costs of the pretreatment. This pretreatment does not remove lignin or any other substances from the biomass; however, the lignin-carbohydrate complexes are cleaved, and the lignin is deposited on the surfaces of the material possibly causing blockage of cellulases to cellulose.

There have been extensive literature reviews on this type of pretreatment over the last decade, focusing on the advantages and disadvantages of the AFEX process used for different feedstocks $[12,19,73,74]$. An overview of some of the advantages include lower moisture content, lower formation of sugar degradation products due to moderate conditions, 100 percent recovery of solid material, and the ability for ammonia to lessen lignin's effect on enzymatic hydrolysis. A smaller number of disadvantages can be seen in the form of costs due to recycle and treatment of chemicals that are being used.

4.2.4. Ammonia Recycle Percolation (ARP). Ammonia recycle percolation (ARP) has been paired with the AFEX pretreatment process by many authors, but it can have some different characteristics that need to be taken into consideration when looking at different pretreatment options. In this process, aqueous ammonia of concentration between 5-15\% (wt\%), is sent through a packed bed reactor containing the biomass feed stock at a rate of about $5 \mathrm{~mL} / \mathrm{min}$. Moderately high temperatures $\left(140^{\circ} \mathrm{C}\right.$ to $\left.210^{\circ} \mathrm{C}\right)$ and longer reactions times are seen in comparison to the AFEX process, creating higher energy costs [128]. A low-liquid ARP (LLARP) process has also been used in which $3.3 \mathrm{~mL} / \mathrm{g}$-biomass and 10 to $12 \mathrm{mi}$ nutes for the liquid throughput and residence times, respectively, have been achieved without any reduction in effectiveness [129].

The advantage with this process over AFEX is its ability to remove a majority of the lignin (75-85\%) and solubilise more than half of the hemicellulose (50-60\%) while maintaining high cellulose content [129]. This is due to the selectivity of ammonia and its ability to break down lignin by ammonolysis while also solubilising hemicellulose over the longer retention times. What is left is a treated solid material consisting of short-chained cellulosic material containing 
TABLE 3: Effect of various pretreatment methods on the chemical composition and chemical/physical structure of lignocellulosic biomass (adapted from [12]). H: high effect, L: low effect, ND: not determined, * Depends on the chemical nature of the solvent.

\begin{tabular}{lccccc}
\hline Pretreatment & $\begin{array}{c}\text { Increases accessible } \\
\text { surface area }\end{array}$ & $\begin{array}{c}\text { Decrystallizes } \\
\text { cellulose }\end{array}$ & $\begin{array}{c}\text { Removes } \\
\text { hemicellulose }\end{array}$ & Removes lignin & $\begin{array}{c}\text { Alters lignin } \\
\text { structure }\end{array}$ \\
\hline Steam explosion & $\mathrm{H}$ & & $\mathrm{H}$ & & $\mathrm{L}$ \\
Liquid hot water & $\mathrm{H}$ & $\mathrm{ND}$ & $\mathrm{H}$ & $\mathrm{L}$ \\
Dilute acid & $\mathrm{H}$ & $\mathrm{H}$ & $\mathrm{H}$ & $\mathrm{H}$ & $\mathrm{H}$ \\
AFEX & $\mathrm{H}$ & $\mathrm{H}$ & $\mathrm{L}$ & $\mathrm{H}$ & $\mathrm{H}$ \\
ARP & $\mathrm{H}$ & $\mathrm{ND}$ & $\mathrm{L}$ & $\mathrm{H}$ & $\mathrm{H}$ \\
Lime & $\mathrm{H}$ & $\mathrm{H}$ & $\mathrm{L}$ & $\mathrm{H}$ or L* & $\mathrm{H}$ \\
Green solvents (NMMO & $\mathrm{H}$ & $\mathrm{H}$ & & $\mathrm{L}$ \\
and ionic liquids) & $\mathrm{H}$ & $\mathrm{H}$ & & $\mathrm{L}$ \\
Supercritical fluid & & & & & \\
\hline
\end{tabular}

a high amount of glucan (removal of 59-70\% lignin, solubilisation of $48-57 \%$ xylan, and $>86 \%$ enzymatic digestibility's achieved) $[9,129]$. Primarily, herbaceous biomass have been most treated with this process- $60-80 \%$ delignification has been achieved for corn stover and 65-85\% delignification for switchgrass [130]. This process will also limit the production of inhibitors to a point where a washout is not needed for processes downstream [131]. High energy costs and liquid loadings, along with many disadvantages associated with the AFEX process, are still some major concerns that need to be addressed before this process is proven to be economical. The ability to retain high cellulose content after pretreatment will help make this process more attractive, however work still needs to be done for overall improvement.

4.2.5. Supercritical Fluid (SCF) Pretreatment. A supercritical fluid is a material which can be either liquid or gas, used in a state above the critical temperature and critical pressure where gases and liquids can coexist. It shows unique properties that are different from those of either gases or liquids under standard conditions-it possesses a liquid like density and exhibits gas-like transport properties of diffusivity and viscosity. Thus, SCF has the ability to penetrate the crystalline structure of lignocellulosic biomass overcoming the mass transfer limitations encountered in other pretreatments [132]. Additionally, supercritical fluids show tunable properties such as partition coefficients and solubility. Small changes in temperature or pressure close to critical point can result in up to 100 -fold changes in solubility, which simplifies separation [133].

Supercritical carbon dioxide $\left(\mathrm{CO}_{2}\right)$ with a critical temperature $\left(T_{c}\right)$ of $31^{\circ} \mathrm{C}$ and a critical pressure $\left(P_{c}\right)$ of 7.4 $\mathrm{MPa}$, has excellent potential for biomass pretreatment. Typically used as an extraction solvent [134] in a number of applications, it has gained importance as a solvent for pretreatment of different varieties of biomass. When used in combination with water, it forms carbonic acid which favors polymer hydrolysis. Once the biomass is pretreated, explosive release of $\mathrm{CO}_{2}$ disrupts the cellulose and hemicellulose structure, thus increasing the accessible surface area for enzyme hydrolysis. The lower temperatures used in the process aids in the stability of the sugars and prevents degradation observed in other pretreatments. Kim and Hong [135] investigated supercritical $\mathrm{CO}_{2}$ pretreatment of hardwood (Aspen) and southern yellow pine with varying moisture contents followed by enzymatic hydrolysis. SCF pretreatment showed significant enhancements in sugar yields when compared to thermal pretreatments without supercritical $\mathrm{CO}_{2}$. Alinia and coworkers [136] investigated the effect of pretreatment of dry and wet wheat straw by supercritical $\mathrm{CO}_{2}$ alone and by a combination of $\mathrm{CO}_{2}$ and steam under different operating conditions (temperature and residence time in the reactors). It was found that a combination of supercritical $\mathrm{CO}_{2}$ and steam gave the best overall yield of sugars. Recent work by Luterbacher and coworkers [137] dealt with high pressure (200 bar) $\mathrm{CO}_{2}-\mathrm{H}_{2} \mathrm{O}$ pretreatment of high loadings $(40 \%)$ of a wide variety of biomass (switchgrass, corn stover, big bluestem, and mixed perennial grasses). The pretreatments were investigated over a wide range of temperatures $\left(150^{\circ} \mathrm{C}\right.$ to $250^{\circ} \mathrm{C}$ ) and residence times of 20 seconds to 60 minutes. It was found that under these operating conditions, a biphasic mixture of $\mathrm{H}_{2} \mathrm{O}$-rich liquid phase and $\mathrm{CO}_{2}$-rich supercritical phase coexists and this greatly aids in pretreatment. Such biphasic pretreatment produced glucose yields of $73 \%$ for wood, $81 \%$ for switchgrass and $85 \%$ for corn stover. Even though SCF is being investigated by a number of researchers for pretreatment, the whole process has not proven to be economically viable with the high pressures involved being a deterrent. Improvements need to done to implement the process on a large scale.

\section{Summary of Lignocellulosic Biomass Pretreatments}

The main aim of pretreatment is to increase accessible surface area, to decrystallize cellulose, and to remove hemicellulose and lignin. The advantages and disadvantages of different methods are listed in Table 1 and the effects of different pretreatments are listed in Table 3 (adapted from Mosier and coworkers [12]). The vast array of biomass types precludes the use of just one type of pretreatment for different feedstocks. What is efficient and economical for one feedstock might not translate to an efficient process for another biomass type. Eggeman and Elander [138] carried out an 
TABLE 4: Capital costs of different pretreatment technologies (adapted from [138]).

\begin{tabular}{|c|c|c|c|c|c|}
\hline Pretreatment method & $\begin{array}{l}\text { Pretreatment direct } \\
\text { fixed capital, } \$ M M\end{array}$ & $\begin{array}{c}\text { Pretreatment } \\
\text { breakdown, \% } \\
\text { Reactor/\% other }\end{array}$ & $\begin{array}{l}\text { Total fixed capital, } \\
\qquad \$ M M\end{array}$ & $\begin{array}{c}\text { Ethanol production, } \\
\mathrm{MM} \mathrm{gal/yr}\end{array}$ & $\begin{array}{l}\text { Total fixed capital, } \\
\text { \$/gal annual capacity }\end{array}$ \\
\hline Dilute acid & 25.0 & $64 / 36$ & 208.6 & 56.1 & 3.72 \\
\hline Hot water & 4.5 & $100 / 0$ & 200.9 & 44.0 & 4.57 \\
\hline AFEX & 25.7 & $26 / 74$ & 211.5 & 56.8 & 3.72 \\
\hline ARP & 28.3 & $25 / 75$ & 210.9 & 46.3 & 4.56 \\
\hline Lime & 22.3 & $19 / 81$ & 163.6 & 48.9 & 3.35 \\
\hline No pretreatment & 0 & - & 200.3 & 9.0 & 22.26 \\
\hline Ideal pretreatment & 0 & - & 162.5 & 64.7 & 2.51 \\
\hline
\end{tabular}

economic analysis of different pretreatment technologies for the Biomass Refining Consortium for Applied Fundamentals and Innovation (CAFI) as part of an initiative of the United States Department of Agriculture. Each pretreatment process was embedded in a full bioethanol facility model and an economic analysis done. The same feedstock for the different pretreatment strategies was used in the analysis, and the resulting solid and fluid streams after pretreatment were characterized, and gathered data were used to close material and energy balances for all the processes. The results of their analysis in terms of the impact of the pretreatment approaches on capital and operating cost investment and glucose and xylose sugar yields are given in Table 4. Their conclusion was that the low-cost pretreatment options are often counterbalanced by the higher costs to recover catalysts/solvents and the higher costs of ethanol product recovery. Thus, there is little difference in the projected economic performance of the different pretreatment options.

However, it was also clearly stated that further process improvements such as identification of optimum enzyme blends for each pretreatment approach and conditioning requirements of the hydrolyzates may lead to greater differentiation of projected process economics. Sendich and coworkers $[139,140]$ used updated parameters and ammonia recovery configurations in the model of Eggeman and Elander and calculated the cost of ethanol production using AFEX. They found out that the minimum ethanol selling price reduced from $\$ 1.41 /$ gal to $\$ 0.81 /$ gal. A new research tool - the Biorefinery and Farm Integration Tool (BFIT) was also developed in which the production of fuel ethanol from cellulosic biomass was integrated with crop and animal production models. Such tools will be beneficial in evaluating the economic viability of biorefinery technologies in different landscapes and also show the effect of the biorefinery in improving farm economics and reducing emissions. A comprehensive economic and life-cycle analysis on the use of green solvents (NMMO and ionic liquids) has not yet been carried out. The advantage in using these solvents is that they can be recovered for reuse and in addition the chemistry of the ILs can be tuned to treat a wide variety of biomass in a single process. High loadings of cellulose can be dissolved, thus leading to high sugar yields when enzymatic hydrolysis is carried out. Current efforts are focused on combining the pretreatment using green solvents with subsequent hydrolysis and fermentation steps (SSF) to maximize the volumetric productivity of the desired product. Such efforts require a greater fundamental understanding of the chemical and physical mechanisms that occur during pretreatment and the effect of the chemical structure of the lignocellulosic biomass on subsequent enzymatic hydrolysis and fermentation. Emphasis is also being placed on genetically modifying organisms to ferment at higher temperature and with a capacity to ferment the xylose so that the yield of ethanol is increased.

\section{Acknowledgments}

Funding for this research was provided by the Southeastern Sun Grant Center, a program supported by the US Department of Transportation. S. Ramakrishnan and J. Collier would also like to thank Bush Brothers for partial financial support. E. Yau would like to thank the Materials Science and Engineering Department at Florida State University, and K. Badal would like to thank the Title III minority graduate engineering program at Florida A\&M University for financial assistance.

\section{References}

[1] "Breaking the Biological Barriers to Cellulosic Ethanol: A joint Research Agenda," Department of Energy, SC-0095. 2005.

[2] M. A. Delucci, Emissions of greenhouse gases from the use of transportation fuels and electricity, Center for Transportation Research, Argonne National Laboratory, Argonne, Ill, USA, 1991.

[3] L. R. Lynd, J. H. Cushman, R. J. Nichols, and C. E. Wyman, "Fuel ethanol from cellulosic biomass," Science, vol. 251, no. 4999, pp. 1318-1323, 1991.

[4] A. Demirbas, "Biofuels securing the planet's future energy needs," Energy Conversion and Management, vol. 50, no. 9, pp. 2239-2249, 2009.

[5] S. T. Merino and J. Cherry, "Progress and challenges in enzyme development for biomass utilization," Advances in Biochemical Engineering/Biotechnology, vol. 108, pp. 95-120, 2007.

[6] M. Leber, "Economics improve for first commercial cellulosic ethanol plants," New York Times, February 2010. 
[7] L. R. Lynd, W. H. Van Zyl, J. E. McBride, and M. Laser, "Consolidated bioprocessing of cellulosic biomass: an update," Current Opinion in Biotechnology, vol. 16, no. 5, pp. 577-583, 2005.

[8] L. R. Lynd, P. J. Weimer, W. H. Van Zyl, and I. S. Pretorius, "Microbial cellulose utilization: fundamentals and biotechnology," Microbiology and Molecular Biology Reviews, vol. 66, no. 3, pp. 506-577, 2002.

[9] B. Yang and C. E. Wyman, "Pretreatment: the key to unlocking low-cost cellulosic ethanol," Biofuels, Bioproducts and Biorefining, vol. 2, no. 1, pp. 26-40, 2008.

[10] M. E. Himmel, S.-Y. Ding, D. K. Johnson et al., "Biomass recalcitrance: engineering plants and enzymes for biofuels production," Science, vol. 315, no. 5813, pp. 804-807, 2007.

[11] H. Palonen, F. Tjerneld, G. Zacchi, and M. Tenkanen, "Adsorption of Trichoderma reesei CBH I and EG II and their catalytic domains on steam pretreated softwood and isolated lignin," Journal of Biotechnology, vol. 107, no. 1, pp. 65-72, 2004.

[12] N. Mosier, C. Wyman, B. Dale et al., "Features of promising technologies for pretreatment of lignocellulosic biomass," Bioresource Technology, vol. 96, no. 6, pp. 673-686, 2005.

[13] M. A. Patel, M. S. Ou, L. O. Ingram, and K. T. Shanmugam, "Simultaneous saccharification and co-fermentation of crystalline cellulose and sugar cane bagasse hemicellulose hydrolysate to lactate by a thermotolerant acidophilic Bacillus sp," Biotechnology Progress, vol. 21, no. 5, pp. 1453-1460, 2005.

[14] C. R. South, D. A. Hogsett, and L. R. Lynd, "Continuous fermentation of cellulosic biomass to ethanol," Applied Biochemistry and Biotechnology, vol. 39-40, no. 1, pp. 587600, 1993.

[15] C. E. Wyman, "Biomass ethanol: technical progress, opportunities, and commercial challenges," Annual Review of Energy and the Environment, vol. 24, pp. 189-226, 1999.

[16] C. E. Wyman, B. E. Dale, R. T. Elander, M. Holtzapple, M. R. Ladisch, and Y. Y. Lee, "Coordinated development of leading biomass pretreatment technologies," Bioresource Technology, vol. 96, no. 18, pp. 1959-1966, 2005.

[17] M. A. Patel, M. S. Ou, R. Harbrucker et al., "Isolation and characterization of acid-tolerant, thermophilic bacteria for effective fermentation of biomass-derived sugars to lactic acid," Applied and Environmental Microbiology, vol. 72, no. 5, pp. 3228-3235, 2006.

[18] C. R. South, D. A. L. Hogsett, and L. R. Lynd, "Modeling simultaneous saccharification and fermentation of lignocellulose to ethanol in batch and continuous reactors," Enzyme and Microbial Technology, vol. 17, no. 9, pp. 797-803, 1995.

[19] YE. Sun and J. Cheng, "Hydrolysis of lignocellulosic materials for ethanol production: a review," Bioresource Technology, vol. 83, no. 1, pp. 1-11, 2002.

[20] M. S. Ou, N. Mohammed, L. O. Ingram, and K. T. Shanmugam, "Thermophilic bacillus coagulans requires less cellulases for simultaneous saccharification and fermentation of cellulose to products than mesophilic microbial biocatalysts," Applied Biochemistry and Biotechnology, vol. 155, no. 1-3, pp. 379-385, 2009.

[21] R. Kumar and C. E. Wyman, "Effects of cellulase and xylanase enzymes on the deconstruction of solids from pretreatment of poplar by leading technologies," Biotechnology Progress, vol. 25, no. 2, pp. 302-314, 2009.

[22] C. Sánchez, "Lignocellulosic residues: biodegradation and bioconversion by fungi," Biotechnology Advances, vol. 27, no. 2, pp. 185-194, 2009.
[23] J. Shi, M. S. Chinn, and R. R. Sharma-Shivappa, "Microbial pretreatment of cotton stalks by solid state cultivation of Phanerochaete chrysosporium," Bioresource Technology, vol. 99, no. 14, pp. 6556-6564, 2008.

[24] Ó. J. Sánchez and C. A. Cardona, "Trends in biotechnological production of fuel ethanol from different feedstocks," Bioresource Technology, vol. 99, no. 13, pp. 5270-5295, 2008.

[25] Y. S. Cheng, Y. Zheng, C. W. Yu, T. M. Dooley, B. M. Jenkins, and J. S. VanderGheynst, "Evaluation of high solids alkaline pretreatment of rice straw," Applied Biochemistry and Biotechnology, vol. 162, no. 6, pp. 1768-1784, 2010.

[26] M. M. Ibrahim, W. K. El-Zawawy, Y. R. Abdel-Fattah, N. A. Soliman, and F. A. Agblevor, "Comparison of alkaline pulping with steam explosion for glucose production from rice straw," Carbohydrate Polymers, vol. 83, no. 2, pp. 720 726, 2011.

[27] S. McIntosh and T. Vancov, "Enhanced enzyme saccharification of Sorghum bicolor straw using dilute alkali pretreatment," Bioresource Technology, vol. 101, no. 17, pp. 67186727, 2010.

[28] D. L. Sills and J. M. Gossett, "Assessment of commercial hemicellulases for saccharification of alkaline pretreated perennial biomass," Bioresource Technology, vol. 102, no. 2, pp. 1389-1398, 2011.

[29] D. G. MacDonald, N. Bakhshi, J. F. Mathews, A. Roychowdhury, P. Bajpai, and M. Moo-Young, "Alkaline treatment of corn stover to improve sugar production by enzymatic hydrolysis," Biotechnology and Bioengineering, vol. 25, no. 8, pp. 2067-2076, 1983.

[30] M. L. Soto, H. Dominguez, M. J. Nunez, and J. M. Lema, "Enzymatic saccharification of alkali-treated sunflower hulls," Bioresource Technology, vol. 49, no. 1, pp. 53-59, 1994.

[31] Y. Zhao, Y. Wang, J. Y. Zhu, A. Ragauskas, and Y. Deng, "Enhanced enzymatic hydrolysis of spruce by alkaline pretreatment at low temperature," Biotechnology and Bioengineering, vol. 99, no. 6, pp. 1320-1328, 2008.

[32] J. Zhu, C. Wan, and Y. Li, "Enhanced solid-state anaerobic digestion of corn stover by alkaline pretreatment," Bioresource Technology, vol. 101, no. 19, pp. 7523-7528, 2010.

[33] Y. Liang, T. Siddaramu, J. Yesuf, and N. Sarkany, "Fermentable sugar release from Jatropha seed cakes following lime pretreatment and enzymatic hydrolysis," Bioresource Technology, vol. 101, no. 16, pp. 6417-6424, 2010.

[34] J. Y. Park, R. Shiroma, M. I. Al-Haq et al., "A novel lime pretreatment for subsequent bioethanol production from rice straw-calcium capturing by carbonation ( $\mathrm{CaCCO}$ ) process," Bioresource Technology, vol. 101, no. 17, pp. 68056811, 2010.

[35] A. T. W. M. Hendriks and G. Zeeman, "Pretreatments to enhance the digestibility of lignocellulosic biomass," Bioresource Technology, vol. 100, no. 1, pp. 10-18, 2009.

[36] Z. Hu, Y. Wang, and Z. Wen, "Alkali $(\mathrm{NaOH})$ pretreatment of switchgrass by radio frequency-based dielectric heating," Applied Biochemistry and Biotechnology, vol. 148, no. 1-3, pp. 71-81, 2008.

[37] R. Sun, J. M. Lawther, and W. B. Banks, "Influence of alkaline pre-treatments on the cell wall components of wheat straw," Industrial Crops and Products, vol. 4, no. 2, pp. 127-145, 1995.

[38] S. C. Rabelo, R. M. Filho, and A. C. Costa, "Lime pretreatment of sugarcane bagasse for bioethanol production," Applied Biochemistry and Biotechnology, vol. 153, no. 1-3, pp. 139-150, 2009. 
[39] C. Martín, H. B. Klinke, and A. B. Thomsen, "Wet oxidation as a pretreatment method for enhancing the enzymatic convertibility of sugarcane bagasse," Enzyme and Microbial Technology, vol. 40, no. 3, pp. 426-432, 2007.

[40] A. B. Bjerre, A. B. Olesen, T. Fernqvist, A. Plöger, and A. S. Schmidt, "Pretreatment of wheat straw using combined wet oxidation and alkaline hydrolysis resulting in convertible cellulose and hemicellulose," Biotechnology and Bioengineering, vol. 49, no. 5, pp. 568-577, 1996.

[41] C. Martín, M. Marcet, and A. B. Thomsen, "Comparison between wet oxidation and steam explosion as pretreatment methods for enzymatic hydrolysis of sugarcane bagasse," BioResources, vol. 3, no. 3, pp. 670-683, 2008.

[42] M. Pedersen and A. S. Meyer, "Influence of substrate particle size and wet oxidation on physical surface structures and enzymatic hydrolysis of wheat straw," Biotechnology Progress, vol. 25, no. 2, pp. 399-408, 2009.

[43] S. Banerjee, R. Sen, R. A. Pandey et al., "Evaluation of wet air oxidation as a pretreatment strategy for bioethanol production from rice husk and process optimization," Biomass and Bioenergy, vol. 33, no. 12, pp. 1680-1686, 2009.

[44] J. Ruffell, B. Levie, S. Helle, and S. Duff, "Pretreatment and enzymatic hydrolysis of recovered fibre for ethanol production," Bioresource Technology, vol. 101, no. 7, pp. 2267-2272, 2010.

[45] N. Szijártó, Z. Kádár, E. Varga, A. B. Thomsen, M. CostaFerreira, and K. Réczey, "Pretreatment of reed by wet oxidation and subsequent utilization of the pretreated fibers for ethanol production," Applied Biochemistry and Biotechnology, vol. 155, no. 1-3, pp. 386-396, 2009.

[46] C. Martín and A. B. Thomsen, "Wet oxidation pretreatment of lignocellulosic residues of sugarcane, rice, cassava and peanuts for ethanol production," Journal of Chemical Technology and Biotechnology, vol. 82, no. 2, pp. 174-181, 2007.

[47] A. S. Schmidt, S. Mallon, A. B. Thomsen, S. Hvilsted, and J. M. Lawther, "Comparison of the chemical properties of wheat straw and beech fibers following alkaline wet oxidation and laccase treatments," Journal of Wood Chemistry and Technology, vol. 22, no. 1, pp. 39-53, 2002.

[48] L. Ping, N. Brosse, P. Sannigrahi, and A. Ragauskas, "Evaluation of grape stalks as a bioresource," Industrial Crops and Products, vol. 33, no. 1, pp. 200-204, 2011.

[49] G. Lissens, H. Klinke, W. Verstraete, B. Ahring, and A. B. Thomsen, "Wet oxidation pre-treatment of woody yard waste: parameter optimization and enzymatic digestibility for ethanol production," Journal of Chemical Technology and Biotechnology, vol. 79, no. 8, pp. 889-895, 2004.

[50] A. Sørensen, P. J. Teller, T. Hilstrøm, and B. K. Ahring, "Hydrolysis of Miscanthus for bioethanol production using dilute acid presoaking combined with wet explosion pretreatment and enzymatic treatment," Bioresource Technology, vol. 99, no. 14, pp. 6602-6607, 2008.

[51] T. I. Georgieva, X. Hou, T. Hilstrøm, and B. K. Ahring, "Enzymatic hydrolysis and ethanol fermentation of high dry matter wet-exploded wheat straw at low enzyme loading," Applied Biochemistry and Biotechnology, vol. 148, no. 1-3, pp. 35-44, 2008.

[52] T. I. Georgieva, M. J. Mikkelsen, and B. K. Ahring, "Ethanol production from wet-exploded wheat straw hydrolysate by thermophilic anaerobic bacterium Thermoanaerobacter BG1L1 in a continuous immobilized reactor," Applied Biochemistry and Biotechnology, vol. 145, no. 1-3, pp. 99-110, 2008.
[53] C. Martín, Y. González, T. Fernández, and A. B. Thomsen, "Investigation of cellulose convertibility and ethanolic fermentation of sugarcane bagasse pretreated by wet oxidation and steam explosion," Journal of Chemical Technology and Biotechnology, vol. 81, no. 10, pp. 1669-1677, 2006.

[54] M. F. Digman, K. J. Shinners, M. D. Casler et al., "Optimizing on-farm pretreatment of perennial grasses for fuel ethanol production," Bioresource Technology, vol. 101, no. 14, pp. 5305-5314, 2010.

[55] C. Li, B. Knierim, C. Manisseri et al., "Comparison of dilute acid and ionic liquid pretreatment of switchgrass: biomass recalcitrance, delignification and enzymatic saccharification," Bioresource Technology, vol. 101, no. 13, pp. 49004906, 2010.

[56] B. Du, L. N. Sharma, C. Becker et al., "Effect of varying feedstock-pretreatment chemistry combinations on the formation and accumulation of potentially inhibitory degradation products in biomass hydrolysates," Biotechnology and Bioengineering, vol. 107, no. 3, pp. 430-440, 2010.

[57] J. Xu, M. H. Thomsen, and A. B. Thomsen, "Pretreatment on corn stover with low concentration of formic acid," Journal of Microbiology and Biotechnology, vol. 19, no. 8, pp. 845-850, 2009.

[58] L. Shuai, Q. Yang, J. Y. Zhu et al., "Comparative study of SPORL and dilute-acid pretreatments of spruce for cellulosic ethanol production," Bioresource Technology, vol. 101, no. 9, pp. 3106-3114, 2010.

[59] C. E. Wyman, B. E. Dale, R. T. Elander et al., "Comparative sugar recovery and fermentation data following pretreatment of poplar wood by leading technologies," Biotechnology Progress, vol. 25, no. 2, pp. 333-339, 2009.

[60] R. Kumar and C. E. Wyman, "Access of cellulase to cellulose and lignin for poplar solids produced by leading pretreatment technologies," Biotechnology Progress, vol. 25, no. 3, pp. 807-819, 2009.

[61] K. J. Zeitsch, The Chemistry and Technology of Furfural and Its Many By-Products, vol. 13 of Sugar Series, Elsevier Science, New York, NY, USA, 2000.

[62] H. Wang, J. Wang, Z. Fang, X. Wang, and H. Bu, "Enhanced bio-hydrogen production by anaerobic fermentation of apple pomace with enzyme hydrolysis," International Journal of Hydrogen Energy, vol. 35, no. 15, pp. 8303-8309, 2010.

[63] Y. H. P. Zhang, S. Y. Ding, J. R. Mielenz et al., "Fractionating recalcitrant lignocellulose at modest reaction conditions," Biotechnology and Bioengineering, vol. 97, no. 2, pp. 214-223, 2007.

[64] T. Marzialetti, M. B. V. Olarte, C. Sievers, T. J. C. Hoskins, P. K. Agrawal, and C. W. Jones, "Dilute acid hydrolysis of loblolly pine: a comprehensive approach," Industrial and Engineering Chemistry Research, vol. 47, no. 19, pp. 71317140, 2008.

[65] M. E. Himmel, W. S. Adney, J. O. Baker et al., "Advanced bioethanol production technologies: a perspective," Fuels and Chemicals from Biomass, vol. 666, pp. 2-45, 1997.

[66] B. C. Saha, L. B. Iten, M. A. Cotta, and Y. V. Wu, "Dilute acid pretreatment, enzymatic saccharification, and fermentation of rice hulls to ethanol," Biotechnology Progress, vol. 21, no. 3, pp. 816-822, 2005.

[67] A. Esteghlalian, A. G. Hashimoto, J. J. Fenske, and M. H. Penner, "Modeling and optimization of the dilute-sulfuricacid pretreatment of corn stover, poplar and switchgrass," Bioresource Technology, vol. 59, no. 2-3, pp. 129-136, 1997. 
[68] Q. A. Nguyen, M. P. Tucker, F. A. Keller, and F. P. Eddy, "Two-stage dilute-acid pretreatment of softwoods," Applied Biochemistry and Biotechnology, Part A, vol. 84-86, pp. 561576, 2000.

[69] P. Sassner, C. G. Mårtensson, M. Galbe, and G. Zacchi, "Steam pretreatment of $\mathrm{H}_{2} \mathrm{SO}_{4}$-impregnated Salix for the production of bioethanol," Bioresource Technology, vol. 99, no. 1, pp. 137-145, 2008.

[70] YE. Sun and J. J. Cheng, "Dilute acid pretreatment of rye straw and bermudagrass for ethanol production," Bioresource Technology, vol. 96, no. 14, pp. 1599-1606, 2005.

[71] B. C. Saha, L. B. Iten, M. A. Cotta, and Y. V. Wu, "Dilute acid pretreatment, enzymatic saccharification and fermentation of wheat straw to ethanol," Process Biochemistry, vol. 40, no. 12, pp. 3693-3700, 2005.

[72] R. A. Silverstein, Y. Chen, R. R. Sharma-Shivappa, M. D. Boyette, and J. Osborne, "A comparison of chemical pretreatment methods for improving saccharification of cotton stalks," Bioresource Technology, vol. 98, no. 16, pp. 3000-3011, 2007.

[73] P. Kumar, D. M. Barrett, M. J. Delwiche, and P. Stroeve, "Methods for pretreatment of lignocellulosic biomass for efficient hydrolysis and biofuel production," Industrial and Engineering Chemistry Research, vol. 48, no. 8, pp. 3713-3729, 2009.

[74] L. da Costa Sousa, S. P. Chundawat, V. Balan, and B. E. Dale, "'Cradle-to-grave' assessment of existing lignocellulose pretreatment technologies," Current Opinion in Biotechnology, vol. 20, no. 3, pp. 339-347, 2009.

[75] J. E. Carrasco, MA. C. Sáiz, A. Navarro, P. Soriano, F. Sáez, and J. M. Martinez, "Effects of dilute acid and steam explosion pretreatments on the cellulose structure and kinetics of cellulosic fraction hydrolysis by dilute acids in lignocellulosic materials," Applied Biochemistry and Biotechnology, vol. 4546, no. 1, pp. 23-34, 1994.

[76] T. A. Lloyd and C. E. Wyman, "Combined sugar yields for dilute sulfuric acid pretreatment of corn stover followed by enzymatic hydrolysis of the remaining solids," Bioresource Technology, vol. 96, no. 18, pp. 1967-1977, 2005.

[77] N. Sun, H. Rodríguez, M. Rahman, and R. D. Rogers, "Where are ionic liquid strategies most suited in the pursuit of chemicals and energy from lignocellulosic biomass?" Chemical Communications, vol. 47, no. 5, pp. 1405-1421, 2011.

[78] Y. Cao, H. Li, Y. Zhang, J. Zhang, and J. He, "Structure and properties of novel regenerated cellulose films prepared from cornhusk cellulose in room temperature ionic liquids," Journal of Applied Polymer Science, vol. 116, no. 1, pp. 547$554,2010$.

[79] H. Zhao, C. L. Jones, G. A. Baker, S. Xia, O. Olubajo, and V. N. Person, "Regenerating cellulose from ionic liquids for an accelerated enzymatic hydrolysis," Journal of Biotechnology, vol. 139, no. 1, pp. 47-54, 2009.

[80] Z. M. Wang, L. Li, K. J. Xiao, and J. Y. Wu, "Homogeneous sulfation of bagasse cellulose in an ionic liquid and anticoagulation activity," Bioresource Technology, vol. 100, no. 4, pp. 1687-1690, 2009.

[81] I. P. Samayam and C. A. Schall, "Saccharification of ionic liquid pretreated biomass with commercial enzyme mixtures," Bioresource Technology, vol. 101, no. 10, pp. 3561-3566, 2010.

[82] Q. Li, Y. C. He, M. Xian et al., "Improving enzymatic hydrolysis of wheat straw using ionic liquid 1-ethyl-3-methyl imidazolium diethyl phosphate pretreatment," Bioresource Technology, vol. 100, no. 14, pp. 3570-3575, 2009.
[83] D. A. Fort, R. C. Remsing, R. P. Swatloski, P. Moyna, G. Moyna, and R. D. Rogers, "Can ionic liquids dissolve wood? Processing and analysis of lignocellulosic materials with 1n-butyl-3-methylimidazolium chloride," Green Chemistry, vol. 9, no. 1, pp. 63-69, 2007.

[84] S. Zhu, Y. Wu, Q. Chen et al., "Dissolution of cellulose with ionic liquids and its application: a mini-review," Green Chemistry, vol. 8, no. 4, pp. 325-327, 2006.

[85] A. P. Dadi, C. A. Schall, and S. Varanasi, "Mitigation of cellulose recalcitrance to enzymatic hydrolysis by ionic liquid pretreatment," Applied Biochemistry and Biotechnology, vol. 137-140, no. 1-12, pp. 407-421, 2007.

[86] A. P. Dadi, S. Varanasi, and C. A. Schall, "Enhancement of cellulose saccharification kinetics using an ionic liquid pretreatment step," Biotechnology and Bioengineering, vol. 95, no. 5, pp. 904-910, 2006.

[87] M. Zavrel, D. Bross, M. Funke, J. Büchs, and A. C. Spiess, "High-throughput screening for ionic liquids dissolving (ligno-)cellulose," Bioresource Technology, vol. 100, no. 9, pp. 2580-2587, 2009.

[88] T. A. D. Nguyen, K. R. Kim, SE. J. Han et al., "Pretreatment of rice straw with ammonia and ionic liquid for lignocellulose conversion to fermentable sugars," Bioresource Technology, vol. 101, no. 19, pp. 7432-7438, 2010.

[89] S. Ramakrishnan, J. Collier, R. Oyetunji, B. Stutts, and R. Burnett, "Enzymatic hydrolysis of cellulose dissolved in N-methyl morpholine oxide/water solutions," Bioresource Technology, vol. 101, no. 13, pp. 4965-4970, 2010.

[90] M. B. Turner, S. K. Spear, J. G. Huddleston, J. D. Holbrey, and R. D. Rogers, "Ionic liquid salt-induced inactivation and unfolding of cellulase from Trichoderma reesei," Green Chemistry, vol. 5, no. 4, pp. 443-447, 2003.

[91] C. H. Kuo and C. K. Lee, "Enhanced enzymatic hydrolysis of sugarcane bagasse by $\mathrm{N}$-methylmorpholine-N-oxide pretreatment," Bioresource Technology, vol. 100, no. 2, pp. 866$871,2009$.

[92] C. H. Kuo and C. K. Lee, "Enhancement of enzymatic saccharification of cellulose by cellulose dissolution pretreatments," Carbohydrate Polymers, vol. 77, no. 1, pp. 41-46, 2009.

[93] M. Shafiei, K. Karimi, and M. J. Taherzadeh, "Pretreatment of spruce and oak by $\mathrm{N}$-methylmorpholine-N-oxide (NMMO) for efficient conversion of their cellulose to ethanol," Bioresource Technology, vol. 101, no. 13, pp. 4914-4918, 2010.

[94] K. E. Perepelkin, "Lyocell fibres based on direct dissolution of cellulose in N-methylmorpholine $\mathrm{N}$-oxide: development and prospects," Fibre Chemistry, vol. 39, no. 2, pp. 163-172, 2007.

[95] T. Rosenau, A. Potthast, H. Sixta, and P. Kosma, "The chemistry of side reactions and byproduct formation in the system NMMO/cellulose (Lyocell process)," Progress in Polymer Science (Oxford), vol. 26, no. 9, pp. 1763-1837, 2001.

[96] N. Kamiya, Y. Matsushita, M. Hanaki et al., "Enzymatic in situ saccharification of cellulose in aqueous-ionic liquid media," Biotechnology Letters, vol. 30, no. 6, pp. 1037-1040, 2008.

[97] S. H. Lee, T. V. Doherty, R. J. Linhardt, and J. S. Dordick, "Ionic liquid-mediated selective extraction of lignin from wood leading to enhanced enzymatic cellulose hydrolysis," Biotechnology and Bioengineering, vol. 102, no. 5, pp. 13681376, 2009.

[98] I. Ballesteros, J. M. Oliva, M. J. Negro, P. Manzanares, and M. Ballesteros, "Enzymic hydrolysis of steam exploded herbaceous agricultural waste (Brassica carinata) at different particule sizes," Process Biochemistry, vol. 38, no. 2, pp. 187192, 2002. 
[99] S. J. B. Duff and W. D. Murray, "Bioconversion of forest products industry waste cellulosics to fuel ethanol: a review," Bioresource Technology, vol. 55, no. 1, pp. 1-33, 1996.

[100] E. Viola, M. Cardinale, R. Santarcangelo, A. Villone, and F. Zimbardi, "Ethanol from eel grass via steam explosion and enzymatic hydrolysis," Biomass and Bioenergy, vol. 32, no. 7, pp. 613-618, 2008.

[101] C. Tengborg, K. Stenberg, M. Galbe et al., "Comparison of $\mathrm{SO}_{2}$ and $\mathrm{H}_{2} \mathrm{SO}_{4}$ impregnation of softwood prior to steam pretreatment on ethanol production," Applied Biochemistry and Biotechnology, Part A, vol. 70-72, pp. 3-15, 1998.

[102] J. Söderström, L. Pilcher, M. Galbe, and G. Zacchi, “Two-step steam pretreatment of softwood with $\mathrm{SO}_{2}$ impregnation for ethanol production," Applied Biochemistry and Biotechnology, Part A, vol. 98-100, pp. 5-21, 2002.

[103] I. Ballesteros, MA. J. Negro, J. M. Oliva, A. Cabañas, P. Manzanares, and M. Ballesteros, "Ethanol production from steam-explosion pretreated wheat straw," Applied Biochemistry and Biotechnology, vol. 130, no. 1-3, pp. 496-508, 2006.

[104] E. Chornet, C. Vanasse, J. P. Lemonnier, and R. P. Overend, "Preparation and processing of medium and high consistency biomass suspensions," Research in Thermochemical Biomass Conversion, pp. 766-778, 1988.

[105] F. Carrasco, "Principles of biomass fractionation," Afinidad, vol. 46, no. 423, pp. 425-429, 1989.

[106] B. Focher, A. Marzett, and V. Crescenzi, Eds., Steam Explosion Techniques, Fundamentals and Industrial Applications, Gordon and Breach, Philadelphia, Pa, USA, 1991.

[107] R. Wooley, M. Ruth, J. Sheehan, and K. Ibsen, "Lignocellulosic biomass to ethanol process design and economics utilizing co-current dilute acid prehydrolysis and enzymatic hydrolysis: current and futuristic scenarios," NREL Report, vol. TP-580-26157, p. 130, 1999.

[108] W. R. Grous, A. O. Converse, and H. E. Grethlein, "Effect of steam explosion pretreatment on pore size and enzymatic hydrolysis of poplar," Enzyme and Microbial Technology, vol. 8, no. 5, pp. 274-280, 1986.

[109] C. Cara, E. Ruiz, I. Ballesteros, M. J. Negro, and E. Castro, "Enhanced enzymatic hydrolysis of olive tree wood by steam explosion and alkaline peroxide delignification," Process Biochemistry, vol. 41, no. 2, pp. 423-429, 2006.

[110] E. Varga, K. Réczey, and G. Zacchi, "Optimization of steam pretreatment of corn stover to enhance enzymatic digestibility," Applied Biochemistry and Biotechnology, Part A, vol. 114, no. 1-3, pp. 509-523, 2004.

[111] M. R. Vignon, C. Garcia-Jaldon, and D. Dupeyre, "Steam explosion of woody hemp chenevotte," International Journal of Biological Macromolecules, vol. 17, no. 6, pp. 395-404, 1995.

[112] C. Cara, E. Ruiz, J. M. Oliva, F. Sáez, and E. Castro, "Conversion of olive tree biomass into fermentable sugars by dilute acid pretreatment and enzymatic saccharification," Bioresource Technology, vol. 99, no. 6, pp. 1869-1876, 2008.

[113] A. Boussaid, Y. Cai, J. Robinson, D. J. Gregg, Q. Nguyen, and J. N. Saddler, "Sugar recovery and fermentability of hemicellulose hydrolysates from steam-exploded softwoods containing bark," Biotechnology Progress, vol. 17, no. 5, pp. 887-892, 2001.

[114] E. Palmqvist and B. Hahn-Hägerdal, "Fermentation of lignocellulosic hydrolysates. II: inhibitors and mechanisms of inhibition," Bioresource Technology, vol. 74, no. 1, pp. 25-33, 2000 .
[115] K. Wang, J.-X. Jiang, F. Xu, R.-C. Sun, and M. S. Baird, "Influence of steam pressure on the physicochemical properties of degraded hemicelluloses obtained from steam-exploded Lespedeza stalks," BioResources, vol. 5, no. 3, pp. 1717-1732, 2010.

[116] X. F. Sun, F. Xu, R. C. Sun, Z. C. Geng, P. Fowler, and M. S. Baird, "Characteristics of degraded hemicellulosic polymers obtained from steam exploded wheat straw," Carbohydrate Polymers, vol. 60, no. 1, pp. 15-26, 2005.

[117] G. Yu, S. Yano, H. Inoue, S. Inoue, T. Endo, and S. Sawayama, "Pretreatment of rice straw by a hot-compressed water process for enzymatic hydrolysis," Applied Biochemistry and Biotechnology, vol. 160, no. 2, pp. 539-551, 2010.

[118] N. Kobayashi, N. Okada, A. Hirakawa et al., "Characteristics of solid residues obtained from hot-compressed-water treatment of woody biomass," Industrial and Engineering Chemistry Research, vol. 48, no. 1, pp. 373-379, 2009.

[119] T. Ingram, T. Rogalinski, V. Bockemühl, G. Antranikian, and G. Brunner, "Semi-continuous liquid hot water pretreatment of rye straw," Journal of Supercritical Fluids, vol. 48, no. 3, pp. 238-246, 2009.

[120] Q. Yu, X. Zhuang, Z. Yuan et al., "Two-step liquid hot water pretreatment of Eucalyptus grandis to enhance sugar recovery and enzymatic digestibility of cellulose," Bioresource Technology, vol. 101, no. 13, pp. 4895-4899, 2010.

[121] Y. Kim, N. S. Mosier, and M. R. Ladisch, "Enzymatic digestion of liquid hot water pretreated hybrid poplar," Biotechnology Progress, vol. 25, no. 2, pp. 340-348, 2009.

[122] J. A. Pérez, I. Ballesteros, M. Ballesteros, F. Sáez, M. J. Negro, and P. Manzanares, "Optimizing Liquid Hot Water pretreatment conditions to enhance sugar recovery from wheat straw for fuel-ethanol production," Fuel, vol. 87, no. 17-18, pp. 3640-3647, 2008.

[123] H. Alizadeh, F. Teymouri, T. I. Gilbert, and B. E. Dale, "Pretreatment of switchgrass by ammonia fiber explosion (AFEX)," Applied Biochemistry and Biotechnology, Part A, vol. 124, no. 1-3, pp. 1133-1141, 2005.

[124] F. Teymouri, L. Laureano-Pérez, H. Alizadeh, and B. E. Dale, "Ammonia fiber explosion treatment of corn stover," Applied Biochemistry and Biotechnology, Part A, vol. 115, no. 1-3, pp. 951-963, 2004.

[125] S. P. S. Chundawat, B. Venkatesh, and B. E. Dale, "Effect of particle size based separation of milled corn stover on AFEX pretreatment and enzymatic digestibility," Biotechnology and Bioengineering, vol. 96, no. 2, pp. 219-231, 2007.

[126] F. Carvalheiro, L. C. Duarte, and F. M. Gírio, "Hemicellulose biorefineries: a review on biomass pretreatments," Journal of Scientific and Industrial Research, vol. 67, no. 11, pp. 849-864, 2008.

[127] L. Lin, R. Yan, Y. Liu, and W. Jiang, "In-depth investigation of enzymatic hydrolysis of biomass wastes based on three major components: cellulose, hemicellulose and lignin," Bioresource Technology, vol. 101, no. 21, pp. 8217-8223, 2010.

[128] T. H. Kim, Y. Y. Lee, C. Sunwoo, and S. K. Jun, "Pretreatment of corn stover by low-liquid ammonia recycle percolation process," Applied Biochemistry and Biotechnology, vol. 133, no. 1, pp. 41-57, 2006.

[129] T. H. Kim and Y. Y. Lee, "Pretreatment and fractionation of corn stover by ammonia recycle percolation process," Bioresource Technology, vol. 96, no. 18, pp. 2007-2013, 2005.

[130] P. V. Iyer, Z. W. Wu, S. B. Kim, and Y. Y. Lee, "Ammonia recycled percolation process for pretreatment of herbaceous biomass," Applied Biochemistry and Biotechnology, Part A, vol. 57-58, pp. 121-132, 1996. 
[131] M. Mes-Hartree, B. E. Dale, and W. K. Craig, "Comparison of steam and ammonia pretreatment for enzymatic hydrolysis of cellulose," Applied Microbiology and Biotechnology, vol. 29, no. 5, pp. 462-468, 1988.

[132] J. McHardy and S. P. Sawan, Supercritical Fluid Cleaning: Fundamentals, Technology and Applications, Noyes Publications, Park Ridge, NJ, USA, 1998.

[133] J. W. King and K. Srinivas, "Multiple unit processing using sub- and supercritical fluids," Journal of Supercritical Fluids, vol. 47, no. 3, pp. 598-610, 2009.

[134] C. Schacht, C. Zetzl, and G. Brunner, "From plant materials to ethanol by means of supercritical fluid technology," Journal of Supercritical Fluids, vol. 46, no. 3, pp. 299-321, 2008.

[135] K. H. Kim and J. Hong, "Supercritical $\mathrm{CO}_{2}$ pretreatment of lignocellulose enhances enzymatic cellulose hydrolysis," Bioresource Technology, vol. 77, no. 2, pp. 139-144, 2001.

[136] R. Alinia, S. Zabihi, F. Esmaeilzadeh, and J. F. Kalajahi, "Pretreatment of wheat straw by supercritical $\mathrm{CO}_{2}$ and its enzymatic hydrolysis for sugar production," Biosystems Engineering, vol. 107, no. 1, pp. 61-66, 2010.

[137] J. S. Luterbacher, J. W. Tester, and L. P. Walker, "High-solids biphasic $\mathrm{CO}_{2}-\mathrm{H}_{2} \mathrm{O}$ pretreatment of lignocellulosic biomass," Biotechnology and Bioengineering, vol. 107, no. 3, pp. 451460, 2010.

[138] T. Eggeman and R. T. Elander, "Process and economic analysis of pretreatment technologies," Bioresource Technology, vol. 96, no. 18, pp. 2019-2025, 2005.

[139] E. Sendich, M. Laser, S. Kim et al., "Recent process improvements for the ammonia fiber expansion (AFEX) process and resulting reductions in minimum ethanol selling price," Bioresource Technology, vol. 99, no. 17, pp. 8429-8435, 2008.

[140] E. D. Sendich and B. E. Dale, "Environmental and economic analysis of the fully integrated biorefinery," Global Change Biology Bioenergy, vol. 1, no. 5, pp. 331-345, 2009. 

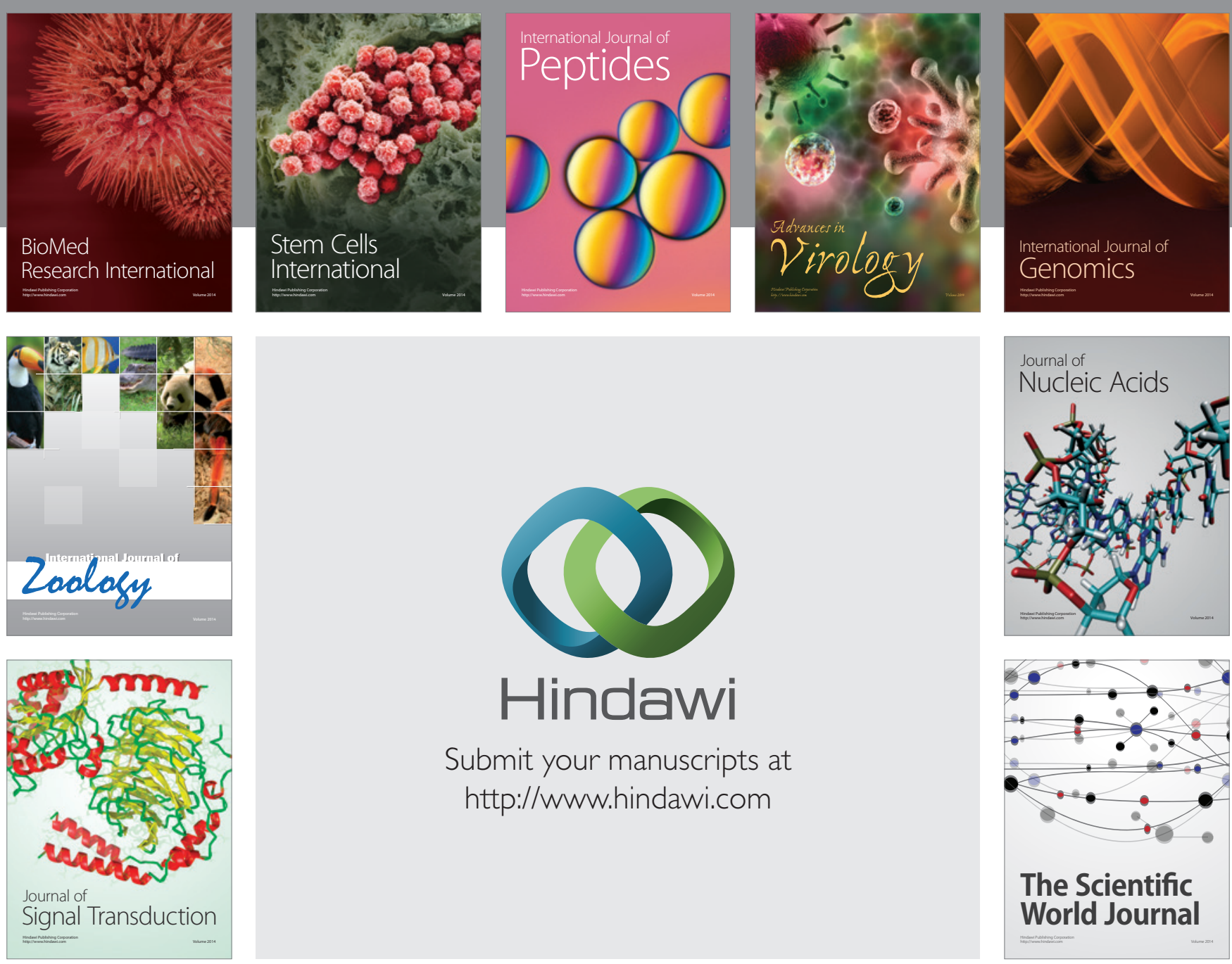

Submit your manuscripts at

http://www.hindawi.com
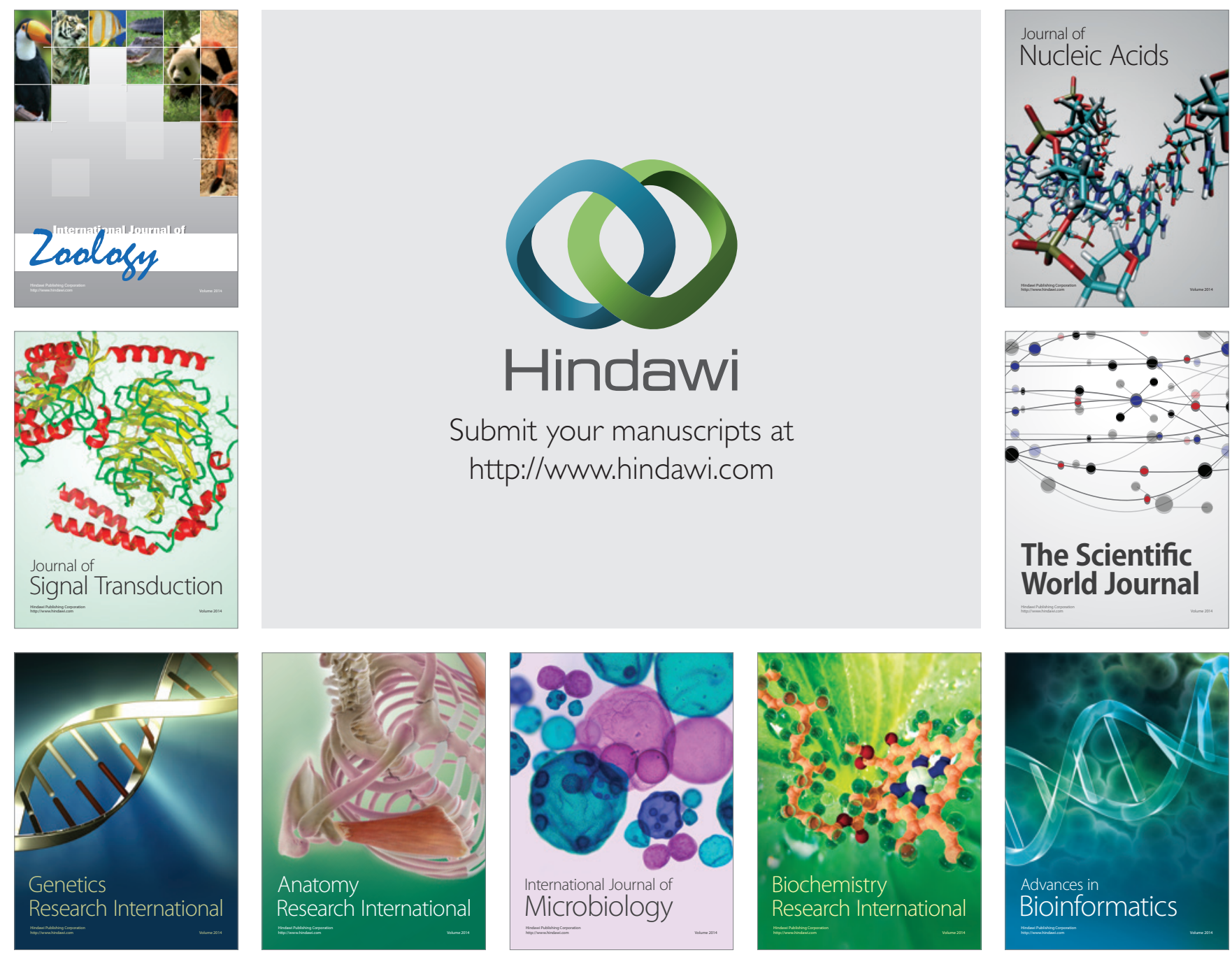

The Scientific World Journal
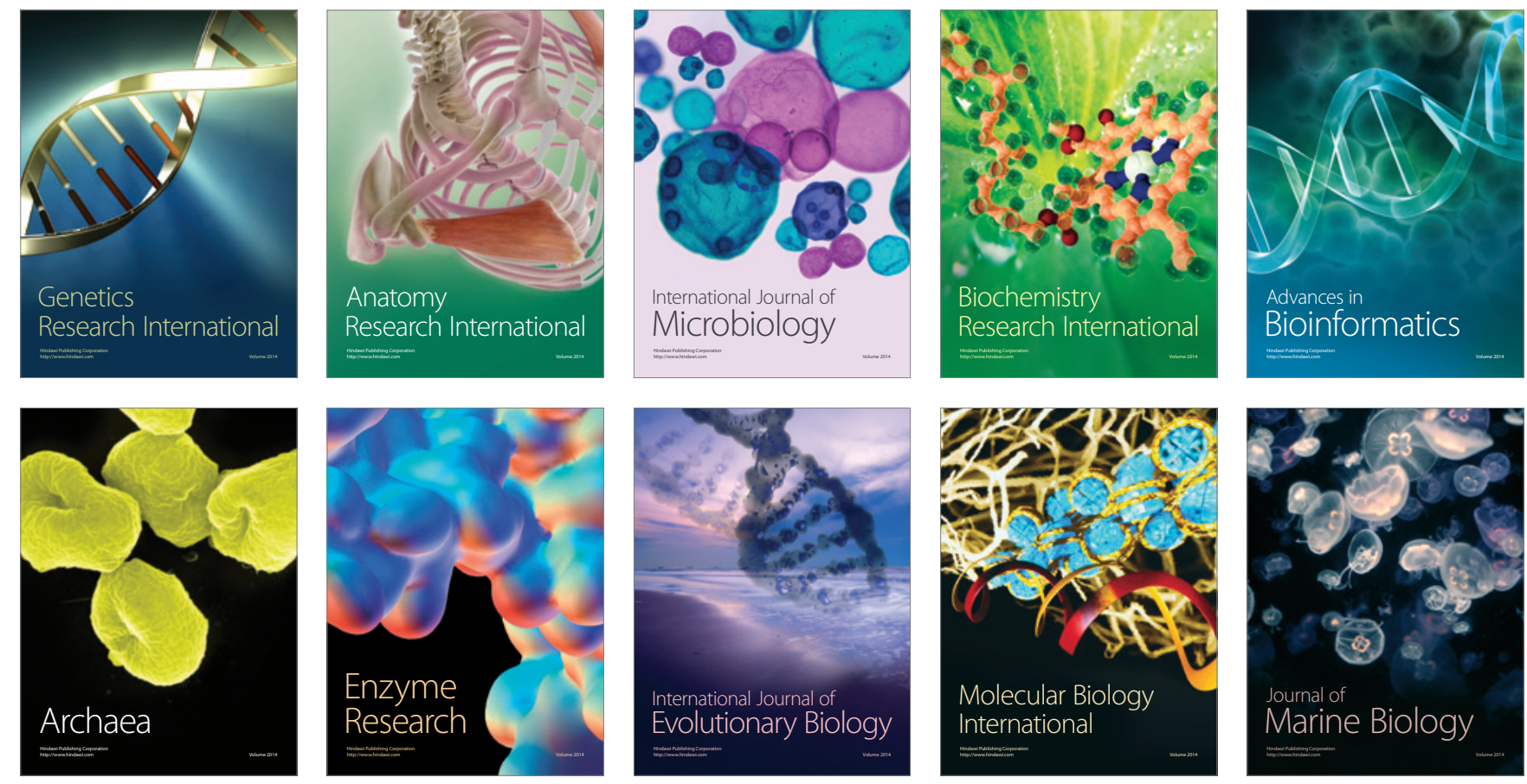